NBER WORKING PAPER SERIES

\title{
LOCKED IN BY LEVERAGE: JOB SEARCH DURING THE HOUSING CRISIS
}

\author{
Jennifer Brown \\ David A. Matsa \\ Working Paper 22929 \\ http://www.nber.org/papers/w22929 \\ NATIONAL BUREAU OF ECONOMIC RESEARCH \\ 1050 Massachusetts Avenue \\ Cambridge, MA 02138 \\ December 2016
}

\begin{abstract}
We are grateful to the data management team at the company that provided the application data for this research. Shumiao Ouyang and Jiaheng Yu provided excellent research assistance. For helpful comments, we also thank Effi Benmelech, Henrik Cronqvist, Thomas Davidoff, Anthony DeFusco, Brian Melzer, as well as seminar participants at Georgetown University, McGill University, University of British Columbia, University of Notre Dame, University of Miami, University of Regensburg, University of Southern California, and LMU Munich Workshop on Natural Experiments and Controlled Field Studies. The views expressed herein are those of the authors and do not necessarily reflect the views of the National Bureau of Economic Research.
\end{abstract}

NBER working papers are circulated for discussion and comment purposes. They have not been peer-reviewed or been subject to the review by the NBER Board of Directors that accompanies official NBER publications.

(C) 2016 by Jennifer Brown and David A. Matsa. All rights reserved. Short sections of text, not to exceed two paragraphs, may be quoted without explicit permission provided that full credit, including $\odot$ notice, is given to the source. 
Locked in by Leverage: Job Search during the Housing Crisis

Jennifer Brown and David A. Matsa

NBER Working Paper No. 22929

December 2016

JEL No. D14,J64,R21,R23

\title{
ABSTRACT
}

This paper examines how housing market distress affects job search. Using data from a leading online job search platform during the Great Recession, we find that job seekers in areas with depressed housing markets apply for fewer jobs that require relocation. With their search constrained geographically, job seekers broaden their search to lower level positions nearby. These effects are stronger for job seekers with recourse mortgages, which we confirm using spatial regression discontinuity analysis. Our findings suggest that housing market distress distorts labor market outcomes by impeding household mobility.

\author{
Jennifer Brown \\ University of British Columbia \\ Sauder School of Business \\ 2053 Main Mall \\ Vancouver, BC V6T 1 Z2 \\ CANADA \\ and NBER \\ jen.brown@sauder.ubc.ca \\ David A. Matsa \\ Kellogg School of Management \\ Northwestern University \\ 2001 Sheridan Road \\ Evanston, IL 60208 \\ and NBER \\ dmatsa@kellogg.northwestern.edu
}


Over the five years following their peak in 2006, U.S. home values fell by more than $22 \%$. The decline in home values, combined with record-high household leverage, evaporated households' housing wealth and set off a chain of events that pushed the U.S. economy into a severe recession that reduced labor demand. During the recession, which started in December 2007, employers laid off more than 3.6 million workers and cut job openings by $44 \%$ (Bureau of Labor Statistics 2009, 2012). Much less is known, however, about how the reduction in housing wealth affected labor supply, including the location and types of jobs that individuals were willing to take.

A popular idea is that the housing bust affected labor supply by reducing household mobility. Liquidity-constrained households might not have the cash required to sell a home with negative equity. Even when a homeowner is not underwater, diminished home equity reduces the amount of capital available to finance a down payment for a new home, which also "locks in" workers to their current location (Stein 1995; Genesove and Mayer 1997). Home price declines might further reduce mobility if households are sensitive to nominal loss aversion (Genesove and Mayer 2001; Engelhardt 2003). Although households could avoid selling by becoming landlords and renting elsewhere, preferences for homeownership and rental market frictions make this an imperfect substitute. As a result, workers facing home price declines might be reluctant to apply to positions that require relocation. ${ }^{1}$

The housing bust could also affect labor supply through a wealth effect. When unemployed workers have lower home equity and net worth, liquidity constraints can make them more willing to accept lower level positions (Chetty 2008; Herkenhoff and Ohanian 2015;

\footnotetext{
${ }^{1}$ At the same time, house value declines could increase mobility if foreclosures force defaulting homeowners out of their homes (Molloy and Shan 2013). We estimate the net effect. Even without price changes, transactions costs of transferring homeownership could interfere with the labor market by reducing workers' mobility (McCormick 1983; Head and Lloyd-Ellis 2012; Blanchflower and Oswald 2013).
} 
Herkenhoff, Phillips, and Cohen-Cole 2016). Consequently, households facing price declines might increase applications to lower level jobs and those requiring only limited experience. ${ }^{2}$

Little is known about the housing bust's effect on labor supply, in part, because it is challenging to separately identify the effect on labor supply from the effect on labor demand. Through an aggregate demand channel, falling home values and tightening credit markets suppress consumer spending, leading to a drop in consumer demand, firm production, and labor demand (Eggertsson and Krugman 2012; Mian and Sufi 2011, 2014; Guerrieri and Lorenzoni 2015). With data only on employment or wages, it is impossible to separate the supply and demand channels empirically. This paper exploits data from a large online job search platform to overcome this identification challenge. ${ }^{3}$ With microdata on nearly four million job applications across the U.S. between May 2008 and December 2009, we hold demand fixed and examine how labor supply to specific jobs is affected by job seekers' housing market conditions.

During the Great Recession, house values and mortgage leverage varied substantially both across locations and over time. Our first identification strategy exploits the fact that local labor markets encompass many hyperlocal housing markets. Job seekers within a labor market have access to the same job postings, but experience different local housing market developments. Because the job application data contain no information on individual job seeker's homeownership or housing wealth, we examine job applications at the ZIP code-month level. For example, within a given local labor market, we compare the changes in job search strategies of applicants in ZIP codes that experienced relatively stable home prices with applicants in nearby ZIP codes that experienced larger price declines.

\footnotetext{
${ }^{2}$ Debt overhang after house price declines could also lead job seekers to be choosier (Donaldson, Piacentino, and Thakor 2015; Bernstein 2016). Again, we estimate the net effect.

${ }^{3}$ We were provided the data under a nondisclosure agreement that restricts us from identifying the online platform. This agreement places no constraints on the conclusions of the analysis.
} 
We find that home value declines and limited home equity lead job seekers to focus their searches on jobs within commuting distance of their home. A $30 \%$ decline in home value is associated with a $15 \%$ decrease in the fraction of applications submitted to jobs out of the applicants' commuting zone. Highly indebted households appear to be particularly tied to their homes: underwater homeowners apply to only half as many distant positions as homeowners with abundant home equity.

With their search constrained geographically, job seekers broaden their search in other ways. They apply for more positions inside their commuting zone by expanding the types of jobs to which they apply. Using job codes assigned by the online platform, we measure the concentration of applicants' job search using a Herfindahl-Hirschman index (HHI) and find that home price declines are associated with less focused local job search. These job codes and job requirements also provide insight into the changing nature of the search. After home value declines, job seekers tilt their search for nearby jobs toward lower level positions. They increase applications to jobs that require little experience, decreasing the fraction of applications to management and executive positions. Consistent with these changes being motivated by the cost of relocation, the effects do not extend to search outside of the commuting zone or hold for ZIP codes dominated by renters.

These effects on job search are particularly pronounced in states with recourse mortgages. Some U.S. states prohibit lenders from pursuing a homeowner's other assets if he or she defaults and the foreclosure sale does not cover the outstanding debt. Because recourse is costly for defaulting homeowners, it makes sense for job seekers with recourse loans to be more locked-in to their homes after a housing market crash than job seekers with nonrecourse loans. Consequently, housing considerations affect job search the most in recourse states. 
Although our first empirical approach is designed to control for the greatest identification challenge (recession-induced variation in labor demand), that approach is susceptible to a subtle selection bias among job seekers. If less mobile individuals within a ZIP code, such as those with less education or those with school-age children, are more likely to search for jobs during housing downturns, then the changes in job search that we estimate could reflect differences in the pool of applicants as opposed to differences in housing-related incentives. To address this potential concern, we exploit the discrete change in recourse laws at state borders.

Using a spatial regression discontinuity framework, we compare ZIP codes near a common state border where mortgage recourse changes. These applicants face the same job opportunities and local economic conditions, yet their job search strategies change discontinuously at the border. Job seekers on the side of the border with recourse mortgages pursue fewer jobs that would require relocation and apply to a broader range and lower level of positions, relative to their counterparts immediately across the border in a nonrecourse state. These effects are strongest in high-income ZIP codes experiencing significant home value declines, where we would expect homeowners to have other valuable assets and be most sensitive to recourse.

Together, the results of the panel and regression discontinuity analyses suggest that housing market fluctuations distort job search. These results complement Bernstein (2016), who finds that some homeowners strategically reduce labor supply when presented with the opportunity for an income contingent mortgage modification. Our analysis shows that nonstrategic motivations also affect distressed homeowners' job search by shifting the location and type of jobs sought. We find that distressed homeowners increase labor supply to some jobs while decreasing labor supply to others. 
By impeding efficient matching in the labor market, housing market frictions likely reduce aggregate productivity and contribute to the Yagan (2016) finding that individuals' location at the onset of the Great Recession affected their labor market participation years later. When workers do not apply to (and, therefore, are not hired for) jobs where their skills are most valued, they forego opportunities to build their on-the-job experience and general human capital. Constrained job search that leads to lower short-term and long-term earnings could exacerbate households' financial distress and reinforce workers' reduced mobility. Firms may also suffer if they are unable to attract workers from the national labor market, potentially preventing them from hiring workers with appropriate skills. More generally, if migration facilitates knowledge transfer between regions, then job seekers who are reluctant to relocate impose an externality on productivity (Serafinelli 2012).

We find that job seekers act as if declines in home value and negative home equity reduce their ability to relocate. Although Ferreira, Gyourko, and Tracy $(2010,2012)$ find that negative equity reduces property sales, it might not reduce households' actual mobility if they rent out the property or suffer a foreclosure-related eviction (Schulhofer-Wohl 2011). Using administrative data from the Netherlands, Struyven (2014) finds that negative equity reduced Dutch owneroccupied mobility during the Great Recession by $20 \%-25 \%{ }^{4}$ U.S. data are less complete, and the results are mixed. Kothari, Saporta-Eksten, and Yu (2013) and Modestino and Dennett (2013) find that the housing bust affected mobility in the U.S., but other studies find no or weak evidence of housing-related mobility declines during the same period (Aaronson and Davis 2011; Donovan and Schnure 2011; Molloy, Smith, and Wozniak 2011; Schmitt and Warner 2011; Farber 2012; Coulson and Grieco 2013; Mumford and Schultz 2013; Bucks and Bricker 2016;

\footnotetext{
${ }^{4}$ Henley (1998) and Chan (2001) find qualitatively similar results in the UK and U.S. following home value declines in the 1990s.
} 
Demyanyk, Hryshko, Luengo-Prado, and Sorensen 2016). Valletta (2013) finds no effect on unemployment durations. Our results highlight the importance of recourse, which could explain why housing distress would affect mobility more in the Netherlands than in the U.S. We are not aware of any other empirical work linking the housing market and mobility to workers' actual labor supply decisions.

It is possible that realized mobility (i.e., actual moves) provides only a coarse measure of housing "lock in" during a deep recession, when job finding rates are low irrespective of search intensity. Because the recession was geographically widespread, mobility (i.e., the ability to move) might not have been particularly beneficial for the unemployed. Indeed, the realized mobility of unemployed renters declined substantially during the Great Recession (Farber 2012), even though we find that renters did not significantly reduce applications to jobs outside of their commuting zone. When unable to find a job, even many mobile job seekers will not move. Through this lens, our results are consistent with researchers' conclusions that the persistent unemployment following the Great Recession was more likely explained by reduced aggregate demand than a structural (geographic) mismatch (e.g., Farber 2012; Kothari, Saporta-Eksten, and Yu 2013).

The remainder of the paper is organized as follows. We describe the data in Section 1 and results from the panel of ZIP codes in Section 2. Section 3 reports results from the spatial regression discontinuity analysis of mortgage recourse at state borders, and Section 4 concludes.

\section{Data}

\subsection{Job applications}

To explore the impact of housing market distress on labor supply, we examine the 
relationship between job seekers' applications and their local housing market conditions. The job application data come from a large online job search platform. The platform allows firms to post job listings and job seekers to apply to these positions. The platform earns revenues from companies posting positions and from advertising; job seekers use the platform for free. All job listings include the job's location and some list experience requirements. Unfortunately, few listings include wages. Job seekers can browse job categories-filtering by location and job characteristics — or search the platform using key words. For most applicants, we only observe his or her ZIP code.

As reported in Table 1, Panel A, the sample includes data on approximately 4 million job applications to almost 60,000 jobs posted in the financial services industry between May 2008 and December 2009. ${ }^{5}$ The job search platform has declined to provide us with data from other industries or time periods. The postings include a wide range of positions, including jobs in retail branches (e.g., tellers, account executives, and financial advisors) and back-office jobs (e.g., telephone bankers, financial analysts, software engineers, and administrative assistants) and are spread across all fifty U.S. states roughly in proportion to population. Applications are also widely dispersed, coming from job seekers in 12,157 ZIP codes. To match the housing market data, we aggregate applications to the ZIP code-month level for our analysis.

Panel B of Table 1 reports characteristics of the applications. To classify the geographic breadth of applicants' search, we match each job applicant and posting to one of 709 commuting zones, defined in 2000 by the U.S. Economic Research Service. Commuting zones delineate local economies, not political boundaries, and approximate local labor markets (Autor and Dorn 2009, 2013). We scale the volume of applications using the ZIP code's number of finance

\footnotetext{
${ }^{5}$ The data are a subsample of the more than 5.5 million applications used by Brown and Matsa (2016) to study labor supply to financially distressed firms. The current analysis examines all applications that include the job seekers' ZIP code for which we observe housing market information.
} 
workers (from the American Community Survey, 2008-2012). Job seekers apply to nearby positions more frequently than they apply to positions located farther away. About three-quarters of applications are to jobs inside the applicant's commuting zone. In an average month, we observe 18.1 applications per 1,000 finance workers inside the commuting zone and 7.2 applications outside.

We also characterize the breadth of job search using a classification provided by the online platform. Posted jobs are assigned up to four of nineteen job codes, such as administrative and clerical, sales, customer service, management, executive, and entry level. We account for heterogeneity in the positions by considering each combination of job codes as a unique job type. By our job type classification, for example, a customer service management position is distinct from a customer service entry-level position. We measure the concentration of applicants' search using a Herfindahl-Hirschman index (HHI), which is the sum of the squared market shares of the job types in a ZIP code-month. Job search concentration, which can range from zero to 10,000 , averages about 2,500 and 3,000 inside and outside of the commuting zone, respectively.

Postings' job codes and experience requirements also indicate a job's level of seniority. Six to eight percent of applications are to management positions, less than one percent are to executive positions, and two to three percent are to entry-level positions. About $11 \%$ of job postings ( $8.5 \%$ of the total applications) specify the years of experience required for the position. When applying to jobs in the applicant's commuting zone that specify experience requirements, $15.2 \%$ of applications are to jobs requiring less than one year of experience. This percentage is lower, $10.9 \%$, when applying outside the commuting zone. 


\subsection{Housing and labor market conditions}

Housing and labor market conditions are summarized in Panel C of Table 1. To measure housing market conditions, we use monthly estimates of median home values at the ZIP codelevel from Zillow to calculate how much home value declined in each ZIP code since January 2006, when home values peaked nationally. Large, positive values reflect large price drops. Between May 2008 and December 2009 (our sample period), home values had fallen an average of $9.4 \%$ from their peak.

We estimate the impact of these price movements on homeowners' home equity using loan servicing information from CoreLogic's Loan-Level Market Analytics database. For purchase and refinance loans, we estimate the property value monthly by inflating (or deflating) the appraised value at origination using the Zillow ZIP code home value index. To filter likely data entry errors, we drop loans in the $1 \%$ tails of loan-to-value at origination. We also exclude loans on commercial property, mixed-use property, residential property with five or more units, manufactured housing, and property for which type is missing. On average in the sample period, $32.3 \%$ of mortgagors had loan-to-value ratios greater than $80 \%$, and $10.3 \%$ owed more than their home was worth.

We also measure local labor market conditions in each month. We measure labor supply in the commuting zone using the unemployment rate (constructed as the population-weighted average of county-level data from the U.S. Bureau of Labor Statistics) and measure labor demand in the commuting zone using the number of finance jobs posted (in our application data) divided by the total number of finance workers in March 2008 (U.S. Census Bureau's County Business Patterns). On average, the unemployment rate is $7.5 \%$, and there are 5.6 job postings per 1,000 workers. 


\section{Panel analysis of job applications and home values}

\subsection{Geographic scope}

By reducing the funds available to finance the down payment for a new home (Stein 1995) or requiring a deficiency payment from the owner in order to sell the home, home value declines could affect homeowners' job search behavior by reducing their mobility. Figure 1 presents a binned scatterplot of the percent of out-of-commuting zone applications against home value declines, along with a smoothed kernel-weighted local polynomial and its $95 \%$ confidence interval. The pattern in the figure is striking: although nearly $30 \%$ of applications are to jobs out of the local labor market when homes have appreciated, these applications fall sharply when home values declines. Relative to places where prices remained flat, ZIP codes in which median home values declined by 20 percentage points are associated with 10 percentage points fewer applications submitted to jobs outside of the local labor market - about a one-third decrease.

These results are robust to controlling for detailed fixed effects and labor market conditions. Table 2 presents results from ZIP code-month regressions, where standard errors are adjusted for clustering at the ZIP code level to account for correlation in unobserved determinants of job seekers' behavior in a ZIP code over time. In a specification without controls, the estimated coefficient on home value decline is negative and statistically significant - a $30 \%$ decrease in home value is associated with a 6.4 percentage point decline in applications to jobs out of the commuting zone, which is a $27 \%$ drop relative to the mean (column 1; $p<0.01)$. Month fixed effects, which account for changing aggregate economic conditions, have little effect on the estimates (column 2). The specifications in columns 3 and 4 account for geography- and labor market-specific differences using 305 MSA or 353 commuting 
zone fixed effects. The estimated coefficient on the home value decline, albeit smaller in magnitude, remains negative and highly statistically significant.

Commuting zone fixed effects control only for fixed differences between local labor markets. To control also for local developments in these markets over time, we include timevarying proxies for labor supply and labor demand in the commuting zone: the local unemployment rate and the local job posting-to-worker ratio. As reported in column 5, the estimated coefficients on these controls have the expected signs. More local unemployment is associated with more applications out of the commuting zone, suggesting that applicants expand their search geographically when the local market is competitive. A scarcity of open positions relative to the local labor force also encourages workers to consider moving to a different market where they might be more likely to find a job. Including these controls for local labor market conditions, however, has little effect on the coefficient on home value decline. A specification with 691 three-digit ZIP code fixed effects accounts for even finer geographic heterogeneity and also yields negative and statistically significant results (column $6 ; p<0.01$ ).

The most demanding specification, presented in column 7, includes ZIP code fixed effects in addition to the local labor market controls and month fixed effects. In this specification, the relationship between home value and job seekers' application behavior is identified from changes in home value within the 12,157 individual ZIP codes over time and after controlling for both aggregate temporal patterns and developments in the local labor market. The estimated coefficient on the home value decline suggests that a $30 \%$ drop in value is associated with a 4.7 percentage point decrease in out-of-commuting zone applications, which is a nearly $20 \%$ decrease relative to the mean $(p<0.01)$.

This decline in the percent of applications to jobs outside of the commuting zone reflects 
both a reduction in applications to distant jobs and an increase in applications to nearby ones. In Table 3, we report the effects on the application volume separately for jobs inside and outside the commuting zone. For each type of application, we examine an indicator for whether any applications were submitted in a ZIP code-month (extensive margin) and the log of the monthly number of applications submitted per worker residing in the ZIP code (intensive margin). Similar to column 7 of Table 2, these regressions control for ZIP code and month fixed effects and the local labor market controls.

A depressed home value is associated with decreased applications to jobs outside of the commuting zone on both the extensive and intensive margins. A 30\% drop in value is associated with a 3.2 percentage point decrease in any distant applications (column $3 ; p<0.01$ ) and, when there are distant applications, a $12.0 \log$ point drop in the number (column $4 ; p<0.01$ ). These results reinforce those in Table 2 and suggest that applicants facing housing distress shift their job search away from positions that would require relocation.

\subsection{Concentration and job type}

Housing market distress and lock-in also affect the types of jobs to which job seekers apply. With less ability to pursue positions farther away, job seekers with diminished home equity expand their job search inside their commuting zone and apply to positions they would not have considered otherwise. As reported in Table 3, a 30\% drop in home value is associated with a 1.8 percentage point increase in any local applications (column $1 ; p<0.01$ ) and, when there are local applications, a $6.0 \log$ point increase in their number (column $2 ; p<0.01$ ).

As these job seekers expand their search locally, they also broaden the types of positions to which they apply. To study the breadth of applicants' search, we examine the concentration 
measure described in Section 1.1. A larger value reflects a more focused job search. Table 4 presents regressions of the concentration measure on home value decline and controls for month fixed effects and labor market conditions. Columns 1-4, which include increasingly demanding geographic controls, examine the concentration of applications to jobs inside the commuting zone.

After home values collapse, searches for nearby jobs become less focused. After controlling for detailed geographic fixed effects at the three- or five-digit ZIP code levels, home value declines are associated with less concentrated search for a position within the commuting zone. ${ }^{6}$ A $30 \%$ decline in home value is associated with a 100-150 unit decrease in the concentration measure, which is a $4 \%-6 \%$ change relative to its mean (columns 3 and $4 ; p<$ 0.01). In contrast, as we would expect, home value declines do not decrease search concentration among positions that require relocation. When examining applications to positions outside the commuting zone, the coefficient on home value decline is positive, relatively small, and not statistically significant (column 5).

To explore the change in job search in greater detail, we examine job postings' type codes and experience requirements. In analysis reported in Table 5, we relate home value decline to the percent of applications submitted to management positions, executive positions, entrylevel positions, and positions requiring less than one year of experience. The analysis in Panel A examines applications to nearby jobs, whereas the analysis in Panel B examines applications to distant ones. Similar to column 7 of Table 2, all specifications control for ZIP code and month fixed effects and the local labor market controls.

\footnotetext{
${ }^{6}$ Estimates from specifications with less detailed geographic controls, reported in columns 1 and 2, are small and not statistically significant. This pattern, which is consistent with depressed ZIP codes having more focused searches before prices fall, underlines the importance of accounting for geographic differences across ZIP codes in this analysis.
} 
As job seekers in distressed housing markets broaden their search, they become less ambitious. When home values decrease, job seekers shift their local search away from management and executive positions. A $30 \%$ decline in home values is associated with $13 \%$ decrease in the fraction of local applications submitted to management positions (column $1 ; p<$ 0.01 ) and a $65 \%$ decrease in the fraction of applications to local executive job postings (column $2 ; p<0.01$ ), relative to their respective means. The opposite may be true for entry-level positions, to which applications increase by $8 \%$, although this estimate is not statistically significant (column 3). Consistent with this interpretation, job seekers increase applications to nearby positions requiring little work experience. A 30\% decrease in home values is associated with a 14 percentage point increase in applications to jobs requiring less than a year of experience, almost doubling applications to those positions (column $4 ; p<0.01$ ).

In contrast, distressed job seekers do not downgrade their search when applying to positions that require relocation. When examining applications to positions outside of the commuting zone, a $30 \%$ decrease in home values is associated with a $46 \%$ decrease in applications to entry-level jobs, relative to the mean (column $7 ; p<0.01$ ). Although this effect is small in absolute terms, it is consistent with distressed job seekers being unwilling to bear the elevated costs of relocation for a low-level position. Although home value decreases are not significantly related to the share of applications submitted to management positions (column 5), executive positions (column 6), or positions requiring less than a year of work experience (column 8), the point estimates for management positions and experience are consistent with the entry-level results. 


\subsection{Heterogeneity in effect}

\subsubsection{Renters}

Housing market distress directly affects job seekers who own their home. We expect renters to be much less sensitive to changes in local home prices, at least in partial equilibrium, and therefore examine their job search as a falsification exercise. Although we cannot identify individual applicants' home ownership status, the homeownership rate in their ZIP code provides a proxy for the likelihood the applicant is constrained by housing debt. To limit the sample to mostly renters, we examine ZIP codes with homeownership rates below $25 \%$ in the 2000 U.S. Census. We repeat the previous analysis on this sample and report the results in Table 6.

As we would expect, renters' job search patterns are less affected by the housing market's collapse. In ZIP codes dominated by renters, a 30\% decline in home values is associated with only 0.8 percentage points fewer applications out of the commuting zone (column 1). The estimate for the breadth of job search is also smaller (column 2). Neither estimate is statistically significant. These estimates are consistent with homeowners' housing market distress explaining the significant effects estimated in our main analytic sample.

\subsubsection{Home equity}

Although loss averse homeowners would hesitate to sell even an unmortgaged home after its value declines, we expect home price declines to have the greatest impact on highly indebted mortgagors. Many households considering relocation rely on their current home equity to fund a down payment on a new home. Thus, the less home equity available, the harder it is to move. In addition to lacking equity to put toward a down payment, households holding underwater mortgages must find cash to cover the shortfall to sell their home. 
We examine the role of mortgage debt in shifting application behavior in analysis reported in Table 7. As expected, low or negative home equity is associated with fewer applications out of the commuting zone (column 1) and less concentrated local job search (column 2). Assuming that only the applications of high loan-to-value mortgagors are affected, the estimates imply that being underwater leads a homeowner to decrease applications out of his or her local labor market by 12.6 percentage points, a more than $50 \%$ decline relative to the mean. The effect is half as big for a household whose equity position is positive but less than $20 \%$ of the property value: these households decrease applications out of the commuting zone by 7.1 percentage points, an almost $30 \%$ decline. The pattern is reversed for job search concentration, which decreases by over $50 \%$ for households with low positive home equity and by $13 \%$ for underwater homeowners. Home equity thus appears to be an important mechanism through which housing market distress affects homeowners' job search strategies.

\subsubsection{Recourse law}

Throughout the U.S., residential mortgage loans are secured by the property. If the borrower defaults, the lender can seize and sell the property to collect on the debt. Homeowners are also personally liable for their mortgage debt in most U.S. states. In these "recourse" states, lenders can pursue other assets from the borrower to collect on any debt not covered by the foreclosure sale. In states without recourse, however, borrowers can default on underwater mortgages without any additional financial liability, because lenders cannot pursue borrowers' other assets to recover the remaining debt. Although not all residents may be aware of a state's debtor protection laws, potential homebuyers and sellers are likely to be informed about recourse by their realtors and lenders. Indeed, personal liability for mortgage debt has real effects. 
Borrowers are less likely to default on recourse mortgages, even when they have substantial negative home equity (Jones 1993; Bhutta, Dokko and Shan 2010; Ghent and Kudlyak 2011).

If housing market conditions affect job seekers' labor supply decisions, then we would expect to find different patterns in recourse and nonrecourse states. Figure 2 displays the nine states with nonrecourse mortgages, based on the classification by Ghent and Kudlyak (2011). ${ }^{7}$ Because recourse is costly for defaulting homeowners, we expect job seekers with recourse loans to be more locked-in to their homes after home values crash than job seekers with nonrecourse loans. As a result, job seekers facing diminished home values in recourse states are likely to engage in more geographically constrained search than other job seekers.

To explore this possibility, we interact home value declines with a recourse indicator in our regression framework and control for local labor market conditions, ZIP code fixed effects, and separate month fixed effects in recourse and nonrecourse states. Because recourse varies only at the state level, its main effect is absorbed by the ZIP code fixed effects. The results are reported in Table 8 .

The geographic breadth of job search is most sensitive to home value declines in recourse states, where defaulting is particularly costly. Housing market conditions have little effect on the geographic breadth of job search in states with nonrecourse mortgages: the coefficient estimate on the uninteracted home value measure is small and not statistically significant. However, the coefficient estimate on the interaction is sizeable and statistically significant, suggesting that job search in recourse states is much more sensitive to housing market conditions. Relative to nonrecourse states, a $30 \%$ decline in home values in a recourse state is associated with 5.1 percentage points fewer applications out of the commuting zone, which is more than a fifth of

\footnotetext{
${ }^{7}$ California and North Carolina allow a mix of recourse and nonrecourse mortgages. Because we do not observe individual loans, we classify these states as recourse, but the results are similar if we classify them as nonrecourse or drop these states altogether.
} 
the sample mean (column $1 ; p<0.01)$.

In-commuting zone job search concentration also responds to housing market distress differently in recourse and nonrecourse states. Whereas home price declines are associated with more focused job search in nonrecourse states, the declines are associated with less focused search in recourse areas, where job seekers are more locked-in to their homes. Relative to nonrecourse states, a 30\% decline in home values in a recourse state is associated with a 310 unit increase in search concentration, which is about $12 \%$ of the sample mean (column $2 ; p<0.01$ ).

\section{Regression discontinuity analysis}

Although our panel analysis finds a robust relationship between home value and the breadth of job search in both geography and type, one might wonder whether the results reflect differences in the type of workers seeking jobs during economic downturns instead of changes in a consistent type of workers' job search. For example, less educated workers are both less mobile (Machin, Salvanes, and Pelkonen 2012) and more exposed to job loss during recessions (Hoynes, Miller, and Schaller 2012). Thus one might ask if the shift in applications toward jobs inside the commuting zone could be because less educated workers are searching, not because of the changing housing market conditions. To address this possibility, we employ a second identification strategy that compares the applications of job seekers, in a narrow region near a state border, who face the same local economic conditions but different housing market-related incentives because of different laws regarding mortgage recourse on either side of the border.

To exploit the discontinuity in recourse regimes at state borders, we restrict the sample to ZIP codes within 50 miles of borders at which recourse laws change. Figure 2 marks the centroids of these ZIP codes on a map of the U.S., using red circles in recourse states and blue 
Xs in nonrecourse ones. This cross-state variation in debtor protection laws results from historical factors, such as foreclosure rates on farms during the Great Depression, and is unrelated to recent aggregate shocks or these narrow regions of the states that we analyze (Ghent 2014; Dobbie and Goldsmith-Pinkham 2015). By comparing job seekers across these neighboring jurisdictions with different recourse regimes, we can confirm that housing market incentives influence job seekers' applications.

The ZIP codes on either side of these borders are quite similar. Table 9 summarizes demographic and economic characteristics of the two sets of ZIP codes, including age, race, education, household income, marital status, household size, population density, owner occupancy, historical mobility, and prevalence of low home equity. The ZIP codes appear very similar across these dimensions. Table 9 also reports the $p$-value of the difference in means, adjusting for clustering at the state level. There is no statistically significant difference in almost all of the ZIP code characteristics analyzed. Of the 38 variables analyzed, only two age measures (under 5 years and over 65 years) and one race measure (black) are statistically different at the $10 \%$ level. As discussed below, the results of the regression discontinuity analysis are robust to including controls for age and race.

To further ensure that we only compare ZIP codes that are in close proximity, we follow Mian, Sufi, and Trebbi (2015) and divide the borders into 10-mile strips. The resulting 10-mile by 50-mile strips of ZIP codes are perpendicular to the state border, and each strip is specific to a border pair (e.g., Minnesota-South Dakota). Throughout our analysis, we control for very local conditions by including fixed effects for these strips. As such, we compare only ZIP codes that lie in the same 10-mile strip running across the state border in question. We also interact these border strip fixed effects with commuting zone fixed effects to ensure that all comparisons are 
within the same commuting zone. For conciseness, we refer to these interacted fixed effects as simply "location" fixed effects.

\subsection{Geographic scope}

Table 10 reports results from regressions of the percent of applications out of the commuting zone on an indicator for whether the state allows recourse mortgages, as well as month and location fixed effects. Job seekers submit 37 percentage points fewer applications to jobs outside of the commuting zone on the recourse side of the border (columns $1 ; p<0.01$ ). After including additional controls for the distance to the border, distance squared, and distance cubed, the estimate's magnitude reduces to 21 percentage points but is still highly statistically significant (columns $2 ; p<0.01$ ).

Because recourse allows lenders to seek deficiency payments from defaulting homeowners, recourse is most salient for homeowners with other valuable assets. In contrast, borrowers without substantial wealth beyond their homes face similar repercussions regardless of recourse. As a proxy for homeowners' wealth, we use ZIP codes' average adjusted gross income (AGI) from the Internal Revenue Service's Statistics of Income for September 2008. We repeat the analysis from column 2 separately on above-median and below-median AGI ZIP codes and report the results in columns 3 and 4, respectively. Recourse is associated with geographically narrower job search in high-income areas but not in low-income areas. In high-income ZIP codes, job seekers apply to 22.5 percentage point more jobs outside of the commuting zone on the recourse side of the border than on the nonrecourse side (column $3 ; p<0.01$ ). But there is essentially no difference in lower income areas (column $4 ; p=0.83$ ).

The discontinuity at the border is readily apparent in a nonparametric analysis. Figure 3 
depicts the percent of applications submitted to jobs outside of the commuting zone in highincome ZIP codes near state borders where recourse changes. We regress this variable on 50 indicators for each one-mile interval on either side of the border, with negative values in states with recourse mortgages, as well as month and location fixed effects. The figure plots the coefficient estimates on the distance indicators in those regressions, along with separate smoothed kernel-weighted local polynomials on either side of the border and their $95 \%$ confidence intervals. The vertical line represents the state border. ZIP codes in states with recourse mortgages are on the left and ZIP codes without recourse are on the right.

Figure 3 reveals a sizeable jump in applications to distant positions. Job seekers in states with recourse mortgages submit substantially fewer applications to jobs outside of their commuting zone relative to their counterparts, just across the state border, who hold nonrecourse mortgages. Although the average fraction of applications to distant positions is somewhat flat as you approach the state border from either side, it jumps discontinuously at the border. Like in the panel analysis reported in Section 2, these reductions seem to reflect both a decrease in applications to distant positions and an increase in applications to positions nearby (see Appendix Figure A1 and Appendix Table A1).

Border ZIP codes in recourse and nonrecourse states are statistically indistinguishable in almost any dimension (see Table 9); however, there are small but statistically significant differences in the prevalence of child, elderly, and black residents. We suspect that these differences result from random variation. Nevertheless, to confirm that these differences cannot explain the regression discontinuity results, we augment the specification in column 3 of Table 10 with the full set of age and race variables listed in Table 9 and report the results in column 5. The jump at the border remains similar in magnitude and is statistically significant $(p<0.05)$. 
We would expect recourse to be most limiting after home values decline substantially. Absent a price drop, homeowners are unlikely to be underwater or face a shortfall in default. In a final specification, we use an indicator to control for ZIP codes with above median declines in home value and interact this variable with the recourse indicator. As expected, we find that applications to distant positions are particularly sensitive to recourse eligibility in places that experience large price drops. The coefficient estimate on the interaction of recourse and large price declines is negative and statistically significant. The jump at the border in applications to jobs outside of the commuting zone is 6.1 percentage points larger in areas suffering more substantial price declines (column 6; $p<0.05$ ). This interaction provides further evidence that the differences in job search behavior are tied to housing related lock-in.

\subsection{Concentration and job types}

Results from the regression discontinuity analysis also confirm our findings about the concentration of applications and types of jobs sought. Table 12 reports results for the concentration of local job search. Except for the dependent variable, the specifications are the same as those presented in Table 11. With their search constrained geographically, job seekers in states with recourse mortgages search more broadly for positions within commuting distance from their home. Job seekers on the recourse side of the border search with 1,000-1,900 units less concentration than job seekers on the opposite side, a $40 \%-75 \%$ reduction relative to the overall sample mean (columns 1 and $2 ; p<0.05$ ).

The effect of recourse on job search concentration comes from high-income ZIP codes, as we would expect. In high-income areas, job search concentration is 1,200 units lower on the recourse side of the border than on the nonrecourse side, a $50 \%$ reduction relative to the mean of 
2,400 in high-income areas (column $3 ; p<0.01$ ). This pattern is not present in low-income ZIP codes, whether the difference is positive, smaller, and not statistically significant (column $4 ; p=$ $0.37)$.

Figure 4, Panel A, displays these results nonparametrically and reveals a discrete jump in local search concentration at the state border. When searching for jobs in their commuting zone, job seekers in states with recourse mortgages submit substantially less concentrated applications than their counterparts, just across the state border, who hold nonrecourse mortgages. Furthermore, the applications' average concentration is mostly flat as you approach the state border from either side, and it jumps discontinuously at the border.

We also examine the concentration of search for distant positions as a falsification test. If job seekers in states with recourse mortgages search more broadly for nearby positions because reduced mobility constrains their search geographically, then we would not expect the same effects on their search for distant positions. Figure 4, Panel B, plots the concentration of applications to positions outside of the job seeker's commuting zone. The concentration of these applications is flat over the whole region, including at the border. The regression analysis also detects no significant difference (Table 11 , column $7 ; p=0.24$ ). This result provides further evidence of the similarity of job seekers on either side of the border in actions not affected by recourse.

Finally, we confirm that recourse reduces local job search concentration the most in areas suffering large price declines. As reported in column 6 of Table 11, the coefficient estimate on the interaction of recourse and large price declines is negative and statistically significant. The drop in the concentration of in-commuting zone applications at the border is 330 units larger in areas suffering substantial price declines (column $6 ; p<0.01$ ). This interaction further reinforces 
the conclusion that housing distress creates lock-in that affects labor supply.

The regression discontinuity analysis also confirms that, as job seekers in distressed housing markets broaden their search, they become less ambitious. Table 12 reports effects on the percent of applications submitted to each of the job types examined in Table 5, presented separately for jobs in (Panel A) and out (Panel B) of the commuting zone. The regressions, which control for month and location fixed effects and a flexible function of distance to the border, are restricted to ZIP codes with above median income.

Job seekers on the side of state borders with recourse mortgages tilt their search toward lower level jobs nearby. When searching for positions in their commuting zone, job seekers submit $59 \%$ more applications to entry-level positions (column $3 ; p<0.10$ ) and $40 \%$ more applications to jobs requiring less than one year of experience (column $4 ; p<0.01$ ), relative to the overall sample means. As a result, the share of applications to management positions drops by $28 \%$ (column $1 ; p<0.05$ ). Although it is imprecisely estimated, the point estimate suggests that recourse also reduces applications to executive positions by $54 \%$ (column $2 ; p=0.43$ ). Appendix Figure A2 plots the discontinuities in these variables at the state borders.

As we would expect, recourse does not cause a similar tilt in applicants' search for jobs that require relocation. We find no evidence that jobs seekers with recourse mortgages apply for more entry-level or limited-experience positions when searching for positions outside of their commuting zone (columns 7 and 8). If anything, these job seekers appear to shift their search for distant jobs in the other direction, increasing applications to management positions by $35 \%$ (column $5 ; p<0.01$ ). Although it is again imprecisely estimated, the point estimate suggests that recourse also increases applications to executive positions by $84 \%$ (column $6 ; p=0.27$ ). Appendix Figure A3 plots the discontinuities in these variables at the state borders. These effects 
are consistent with locked-in job seekers being willing to bear the elevated costs of relocation only for a high-level position.

\section{Conclusion}

We match a unique data set from a large online job search platform to housing market data to explore the relationship between home values and workers' labor supply decisions. We find that home value declines and negative equity lead job seekers to focus their searches on jobs within their commuting zone. Constrained geographically, job seekers broaden their search in other ways by considering lower level positions and those requiring less experience. These effects are more pronounced in recourse states where lenders can go after a defaulting homeowner's other assets. As a result, we find discontinuous jumps in workers' job search strategies at borders between recourse and nonrecourse states. After house values decline, it appears that job seekers lack the liquidity to fund the down payment for a new home or a protracted job search.

Housing-related constraints on job search have mixed implications for firms. When workers focus their searches on jobs nearby, firms lose access to the national labor market. At the same time, in areas where job seekers are locked in to their homes, firms face less competition from the broader labor market. These firms gain access to workers who are more qualified for a given position and, potentially, hire workers at lower cost.

From the workers' perspective, these outcomes are costly and potentially long-lived. Workers who accept positions below their skill or experience levels forego opportunities to build their human capital. Moreover, constrained workers, who apply to jobs they would otherwise have avoided, crowd out other job seekers. For example, an experienced manager who applies to 
a lower level position can displace a younger worker from that job opportunity. Even if housing market constraints are short-lived, they can impose long run costs on both workers. Indeed, employment status during a recession affects labor market outcomes years later (Yagan 2016). The broader labor market impact and distributional consequences of constrained mobility are important areas for future research.

\section{References}

Aaronson, Daniel, and Jonathan Davis. 2011. How much has house lock affected labor mobility and the unemployment rate? Chicago Fed Letter 290.

Autor, David, and David Dorn. 2009. This Job Is "Getting Old": Measuring Changes in Job Opportunities Using Occupational Age Structure. American Economic Review 99(2): 4551.

Autor, David, and David Dorn. 2013. The Growth of Low-Skill Service Jobs and the Polarization of the U.S. Labor Market. American Economic Review 103(5), 1533-1597.

Bernstein, Asaf. 2016. Household Debt Overhang and Labor Supply. Working paper.

Bhutta, Neil, Jane Dokko, and Hui Shan. 2010. The Depth of Negative Equity and Mortgage Default Decisions. Finance and Economics Discussion Series Working Paper 2010-35, Federal Reserve Board of Governors.

Blanchflower, David G., and Andrew J. Oswald. 2013. Does High Home-Ownership Impair the Labor Market? NBER Working Paper 19079.

Bricker, Jesse, and Brian Bucks. 2016. Negative home equity, economic insecurity, and household mobility over the Great Recession. Journal of Urban Economics 91: 1-12.

Brown, Jennifer, and David Matsa. 2016. Boarding a Sinking Ship? An Investigation of Job Applications to Distressed Firms. Journal of Finance 71(2): 507-550.

Bureau of Labor Statistics. 2009. Mass Layoff Statistics. http://www.bls.gov/mls/mowevsep20082009.htm

Bureau of Labor Statistics. 2012. BLS Spotlight on Statistics: The Recession of 2007-2009. http://www.bls.gov/spotlight/2012/recession/pdf/recession_bls_spotlight.pdf 
Chan, Sewin. 2001. Spatial lock-in: do falling house prices constrain residential mobility? Journal of Urban Economics 49(3), 567-586.

Chetty, Raj. 2008. Moral Hazard versus Liquidity and Optimal Unemployment Insurance. Journal of Political Economy 116(2), 173-234.

Coulson, N. Edward, and Paul LE Grieco. 2013. Mobility and mortgages: Evidence from the PSID. Regional Science and Urban Economics 43(1): 1-7.

Demyanyk, Yuliya S., Dmytro Hryshko, María José Luengo-Prado, and Bent E. Sørensen. 2013. Moving to a job: The role of home equity, debt, and access to credit. Working paper

Dobbie, Will, and Paul Goldsmith-Pinkham. 2015. Debtor Protections and the Great Recession. Princeton University. Working paper.

Donaldson, Jason Roderick, Giorgia Piacentino, and Anjan Thakor. 2015. Bank Capital, Bank Credit, and Unemployment. Working paper.

Donovan, Colleen, and Calvin Schnure. 2011. Locked in the House: Do Underwater Mortgages Reduce Labor Market Mobility? Working paper.

Eggertsson, Gauti B., and Paul Krugman. 2012. Debt, Deleveraging, and the Liquidity Trap: A Fisher-Minsky-Koo Approach. Quarterly Journal of Economics 127: 1469-1513.

Engelhardt, Gary V. 2003. Nominal loss aversion, housing equity constraints, and household mobility: evidence from the United States. Journal of Urban Economics 53(1): 171-195.

Farber, Henry S. 2012. Unemployment in the Great Recession: Did the housing market crisis prevent the unemployed from moving to take jobs? American Economic Review 102(3): $520-525$.

Ferreira, Fernando, Joseph Gyourko, and Joseph Tracy. 2010. Housing busts and household mobility. Journal of Urban Economics 68: 34-45.

Ferreira, Fernando, Joseph Gyourko, and Joseph Tracy. 2012. Housing Busts and Household Mobility: An Update. Federal Reserve Bank of New York Economic Policy Review, November: $1-15$.

Genesove, David, and Christopher Mayer. 1997. Equity and time to sale in the real estate market. American Economic Review 87(3), 255-269.

Genesove, David, and Christopher Mayer. 2001. Loss-aversion and seller behavior: evidence from the housing market. Quarterly Journal of Economics 116(4), 1233-1260.

Ghent, Andra C. 2014. How Do Case Law and Statute Differ? Lessons from the Evolution of Mortgage Law. Journal of Law and Economics 57(4): 1085-1122. 
Ghent, Andra C., and Marianna Kudlyak. 2011. Recourse and Residential Mortgage Default: Evidence from U.S. States. Review of Financial Studies 24(9): 3139-3186.

Guerrieri, Veronica, and Guido Lorenzoni. 2015. Credit Crises, Precautionary Savings, and the Liquidity Trap. NBER Working Paper 17583.

Head, Allen, and Huw Lloyd-Ellis. 2012. Housing liquidity, mobility, and the labor market. Review of Economic Studies, 79: 1559-1589.

Herkenhoff, Kyle F., and Lee E. Ohanian. 2015. The Impact of Foreclosure Delay on US Employment. NBER Working Paper 21532.

Herkenhoff, Kyle, Gordon Phillips, and Ethan Cohen-Cole. 2016. How Credit Constraints Impact Job Finding Rates, Sorting \& Aggregate Output. NBER Working Paper 22274

Hoynes, Hilary, Douglas L. Miller, and Jessamyn Schaller. 2012. Who suffers during recessions? Journal of Economic Perspectives 26(3): 27-47.

Jones, Lawrence D. 1993. Deficiency Judgments and the Exercise of the Default Option in Home Mortgage Loans. Journal of Law and Economics 36:115-38.

Kothari, Siddharth, Itay Saporta-Eksten, and Edison Yu. 2013. The (un)importance of geographical mobility in the Great Recession. Review of Economic Dynamics 16(3): 553563.

Machin, Stephen, Kjell G. Salvanes, and Panu Pelkonen. 2012. Education and mobility. Journal of the European Economic Association 10(2): 417-450.

McCormick, B. 1983. Housing and unemployment in Great Britain. Oxford Economic Papers, 35(S): 283-305.

Mian, Atif, and Amir Sufi. 2011. House prices, home equity-based borrowing, and the U.S. household leverage crisis. American Economic Review 101: 2132-56.

Mian, Atif, and Amir Sufi. 2014. What Explains the 2007-2009 Drop in Employment? Econometrica 82: 2197-2223.

Mian, Atif, Amir Sufi, and Francesco Trebbi. 2015. Foreclosures, house prices, and the real economy. Journal of Finance 70(6): 2587-2634.

Modestino, Alicia Sasser, and Julia Dennett. 2013. Are American homeowners locked into their houses? The impact of housing market conditions on state-to-state migration. Regional Science and Urban Economics 43(2): 322-337.

Molloy, Raven, and Hui Shan. 2013. The post-foreclosure experience of U.S. households. Real Estate Economics 41(2): 225-254. 
Molloy, Raven, Christopher L. Smith, and Abigail Wozniak. 2011. Internal migration in the United States. The Journal of Economic Perspectives 25(3): 173-196.

Mumford, Kevin J., and Katie Schultz. 2013. The Effect of Underwater Mortgages on Unemployment. Working paper.

Schmitt, John, and Kris Warner. 2011. Deconstructing structural unemployment. Center for Economic Policy research report 2011-6.

Schulhofer-Wohl, Sam. 2011. Negative equity does not reduce homeowners' mobility. NBER Working Paper 16701.

Serafinelli, Michel. 2012. Good firms, worker flows, and productivity. Working paper.

Stein, Jeremy. 1995. Prices and trading volume in the housing market: A model with downpayment effects. Quarterly Journal of Economics 110: 379-406.

Struyven, Daan. 2014. Housing lock: Dutch evidence on the impact of negative home equity on household mobility. Working Paper.

Valletta, Robert G. 2013. House lock and structural unemployment. Labour Economics 25: 8697.

Yagan, Danny. 2016. Is the Great Recession Really Over? Longitudinal Evidence of Enduring Employment Impacts. Working paper. 
Figure 1

\section{Applications out of the commuting zone and home values}

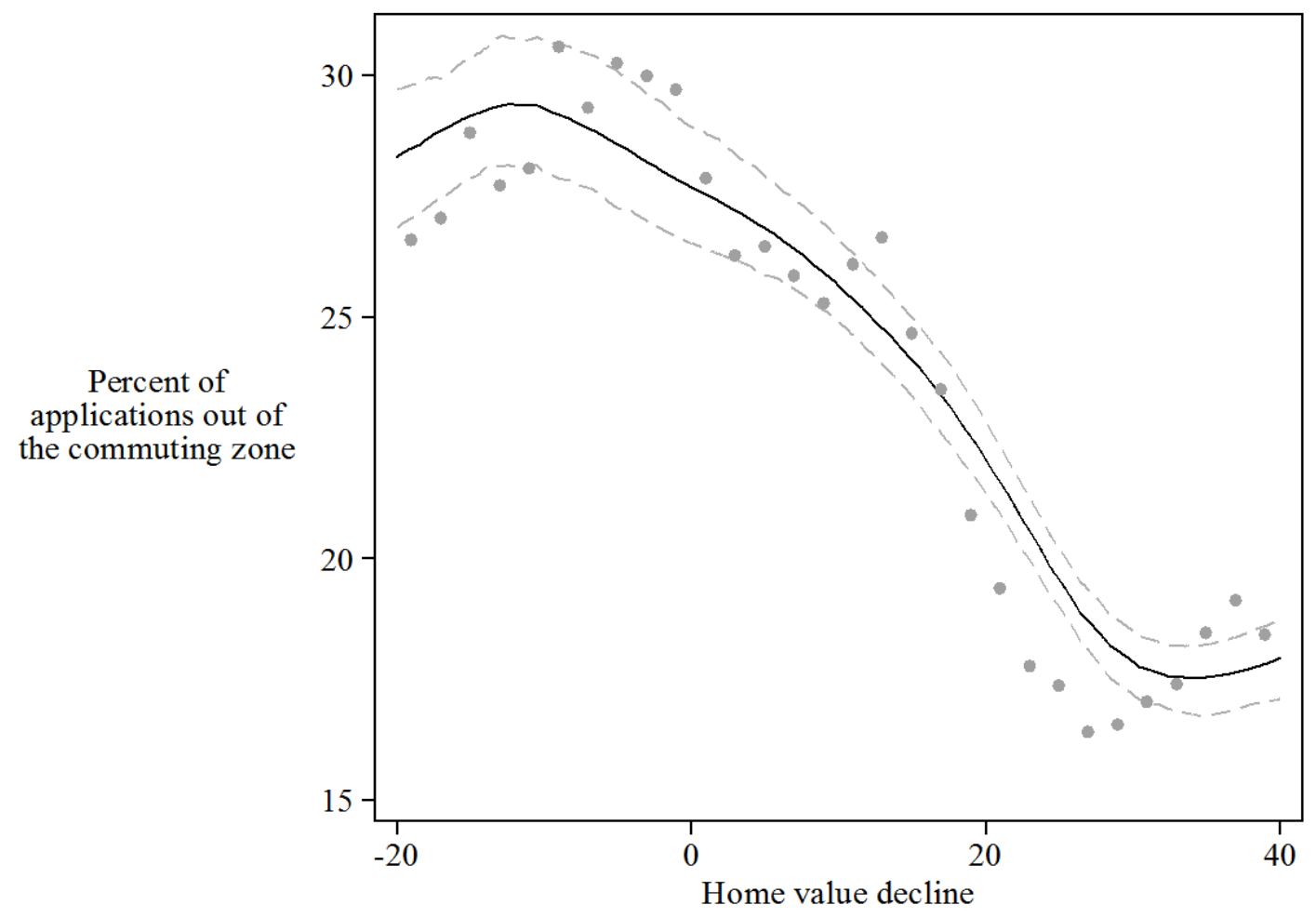

This figure presents a binned scatterplot of the percent of applications to jobs out of the commuting zone against home value decline (from January 2006, \%). The sample consist of ZIP code-months between May 2008 and December 2009, and the bins are two units wide. Percent of applications out of the commuting zone is weighted by the total number of applications submitted from the ZIP code that month. The lines represent a smoothed kernelweighted local polynomial and its $95 \%$ confidence interval, calculated by bootstrapping clustered at the ZIP code level. 
Figure 2

Recourse status by U.S. state and regression discontinuity design

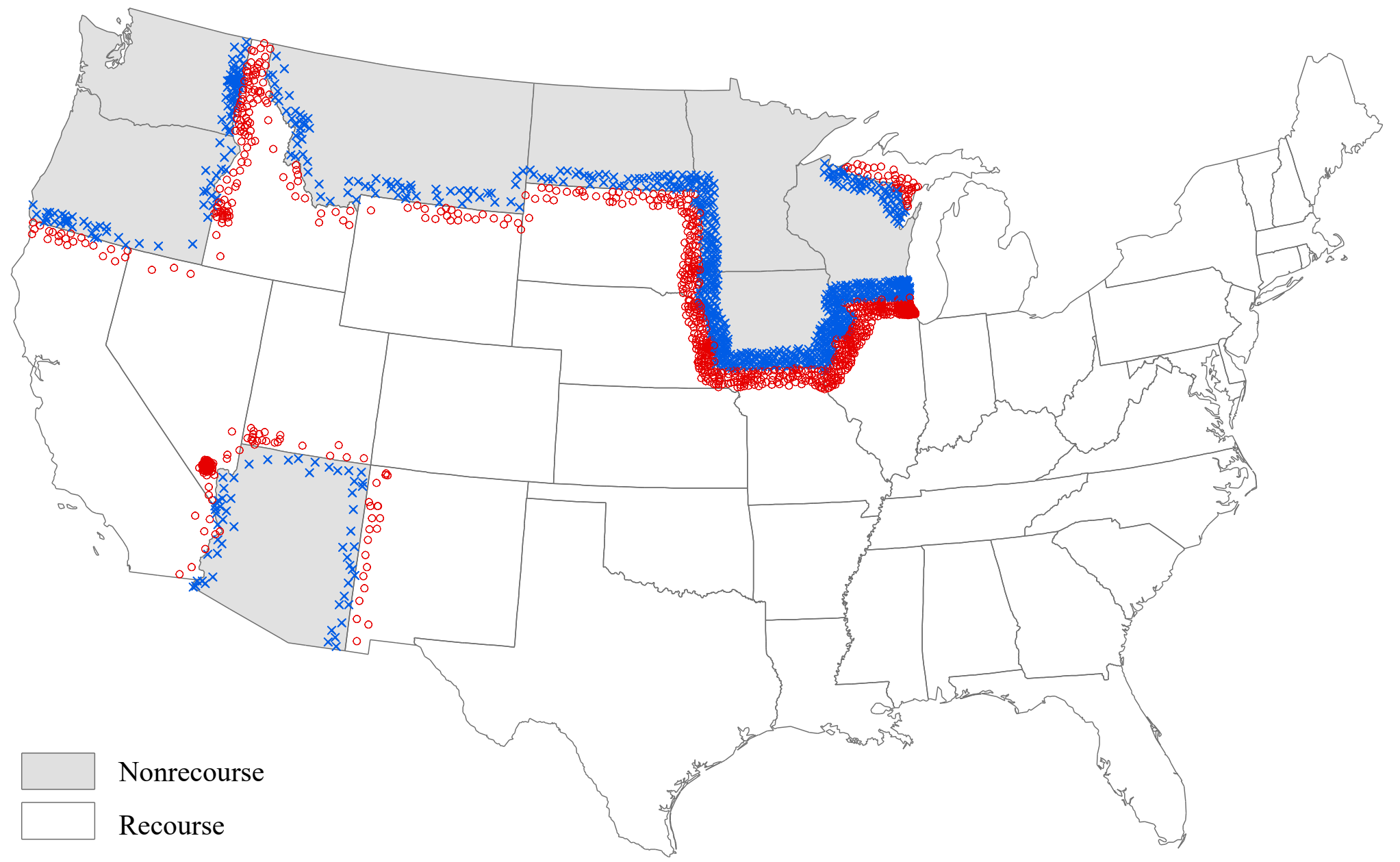

This figure categorizes states in the contiguous U.S. by whether most residential mortgage lenders can seize a borrower's personal assets if the borrower defaults and owes more than the property is worth. Alaska has nonrecourse mortgages, and Hawaii allows recourse. ZIP codes within 50 miles of state borders where recourse law changes are marked with blue Xs (nonrecourse) and red circles (recourse). 
Figure 3

Percent of applications to jobs out of the commuting zone

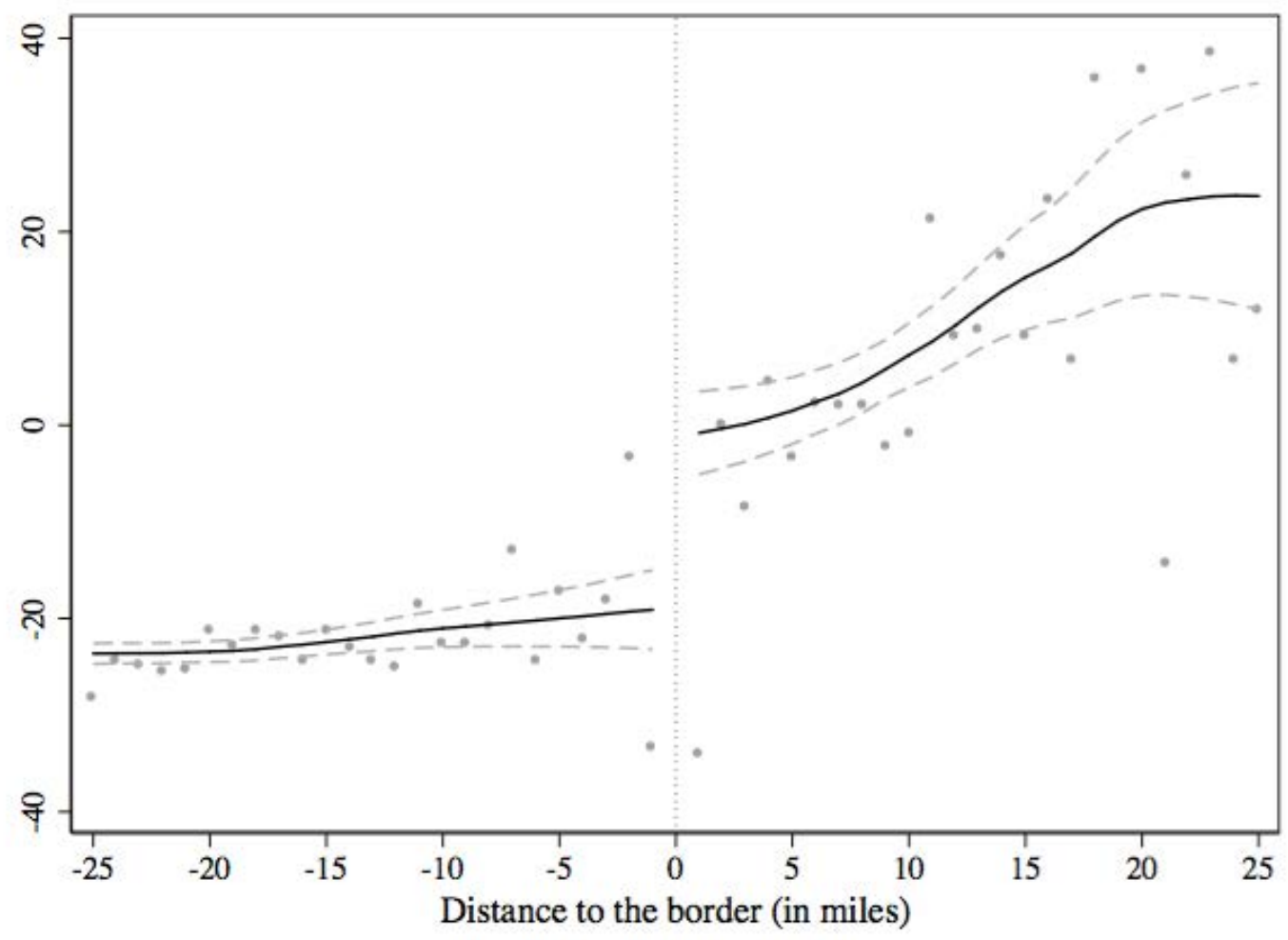

This figure plots the percent of applications to jobs out of the commuting zone for the months between May 2008 and December 2009 for U.S. ZIP codes that are near a state border where recourse law changes and had above median adjusted gross income in 2006. We regress the percent of applications on one-mile distance-to-the-border indicators, and month and location (10-mile border strip $\times$ commuting zone) fixed effects. The distances are labeled as negative for states with recourse mortgages. The figure plots the coefficients on these dummies, along with separate smoothed kernel-weighted local polynomials on either side of the border and their $95 \%$ confidence intervals. 
Figure 4

Concentration of job applications

Panel A. In the commuting zone

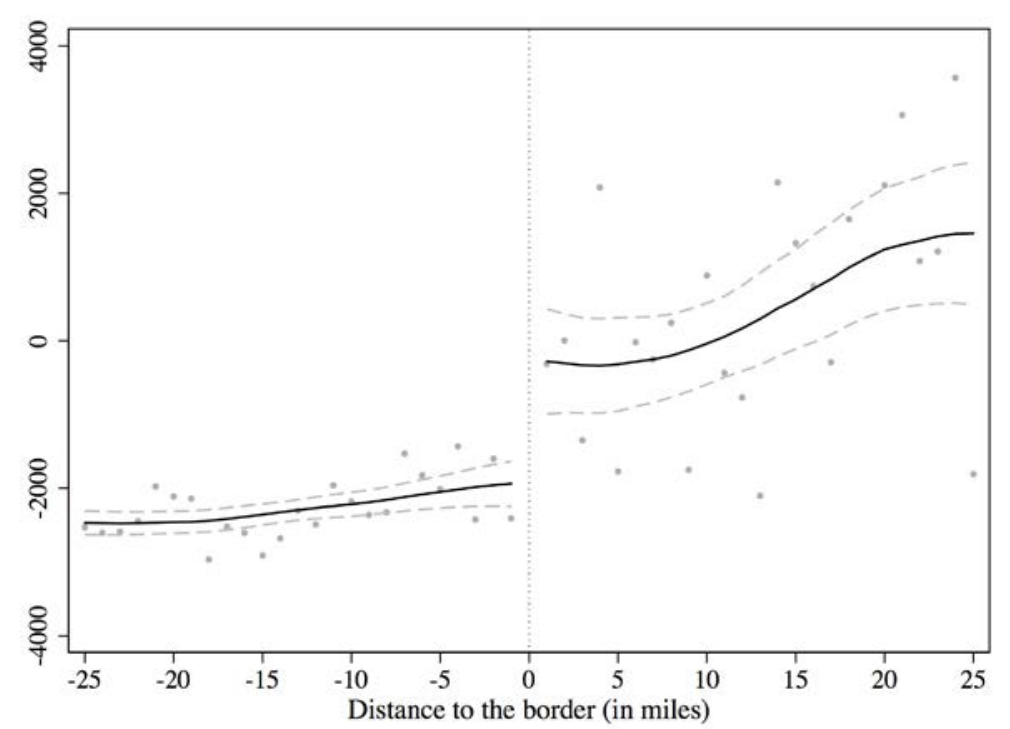

Panel B. Out of the commuting zone

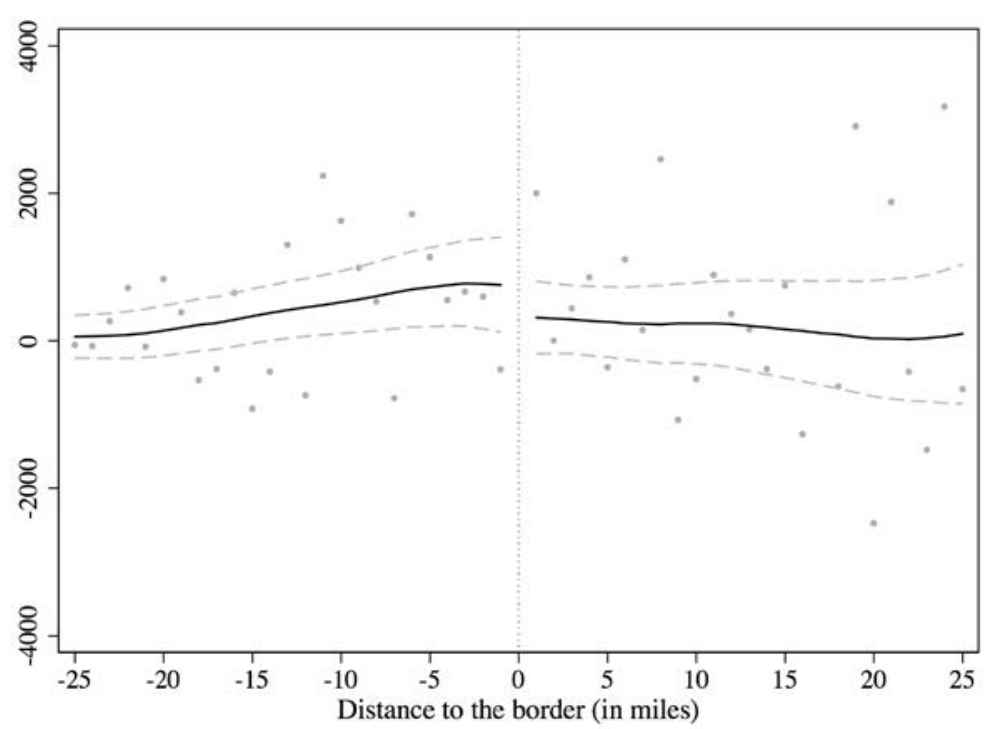

These figures plot the concentration of applications to jobs in (Panel A) and out (Panel B) of the commuting zone for the months between May 2008 and December 2009 for U.S. ZIP codes that are near a state border where recourse law changes and had above median adjusted gross income in 2006. Variables are defined as in Table 1, and the methodology used is the same as in Figure 3. The distances are labeled as negative for states with recourse mortgages. 
Table 1

Summary statistics

\section{Panel A. Job postings}

Number of job postings

59,469

Number of applications

$3,997,972$

Number of ZIP codes

12,157

Panel B. Application characterics

(ZIP code-month level, $N=180,232$ )

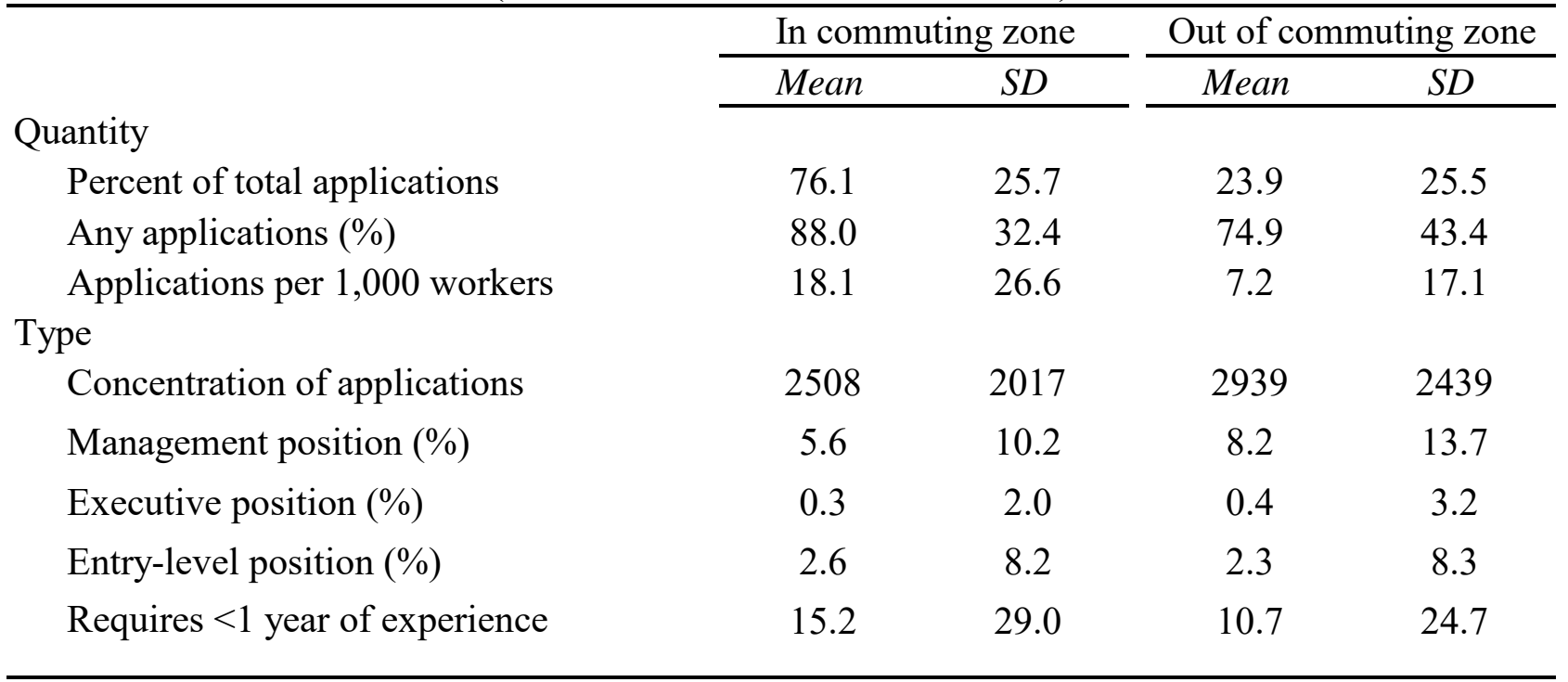

Home value decline (from January 2006, \%)

\begin{tabular}{cc} 
Mean & $S D$ \\
\hline 9.4 & 16.4 \\
22.0 & 8.6 \\
10.3 & 14.2 \\
7.5 & 1.8 \\
5.6 & 3.6
\end{tabular}

This table reports summary statistics for the application sample, which includes applications to 59,469 jobs at large financial services firms between May 2008 and December 2009. Panel A describes the job postings. Panel B summarizes application characteristics separately for jobs in and out of the applicant's commuting zone, as defined by the U.S. Economic Research Service in 2000. The percent of total applications in (and out) of the commuting zone is weighted by the number of applications submitted from the ZIP code that month. The volume of applications is scaled by the number of finance workers (in thousands) in the ZIP code, based on the American Community Survey, 2008-2012. Posted jobs are assigned up to four of nineteen job codes by the online platform, and each combination of job codes defines a unique job type. The concentration of applications is measured by a Herfindahl-Hirschman index based on the shares of these job types in a ZIP code-month. Management, executive, and entry-level positions are classified using the job codes. These job type variables are weighted by the number of applications submitted to jobs in (or out) of the commuting zone from the ZIP code that month. Required experience is weighted by the number of applications for which experience information is available (in the commuting zone, mean $=5.2, S D=7.5, N=40,984$; out of the commuting zone, mean $=3.5 S D=3.1, N$ $=29,628)$. Panel C describes local economic conditions. ZIP code-level home value decline since January 2006 is based on monthly estimates of median home value from Zillow. Home equity measures are estimated from CoreLogic's Loan-Level Market Analytics database. The commuting zone unemployment rate is the weighted average of county-level data from the U.S. Bureau of Labor Statistics. The number of jobs posted in the commuting zone is divided by the total number of finance workers (in thousands) in March 2008, based on the U.S. Census Bureau's County Business Patterns. 
Table 2

Applications out of the commuting zone and home values

\begin{tabular}{|c|c|c|c|c|c|c|c|}
\hline \multicolumn{8}{|c|}{ Dependent variable: Percent of applications out of the commuting zone } \\
\hline & $(1)$ & $(2)$ & $(3)$ & (4) & $(5)$ & $(6)$ & (7) \\
\hline Home value decline & $\begin{array}{c}-0.212 * * * \\
(0.020)\end{array}$ & $\begin{array}{c}-0.232 * * * \\
(0.021)\end{array}$ & $\begin{array}{c}-0.138 * * * \\
(0.042)\end{array}$ & $\begin{array}{c}-0.107 * * * \\
(0.023)\end{array}$ & $\begin{array}{c}-0.115^{* * *} \\
(0.023)\end{array}$ & $\begin{array}{c}-0.249 * * * \\
(0.026)\end{array}$ & $\begin{array}{c}-0.155^{* * *} \\
(0.016)\end{array}$ \\
\hline $\begin{array}{l}\text { Local labor market conditions } \\
\% \text { unemployment }\end{array}$ & & & & & $\begin{array}{c}0.730 * * * \\
(0.117)\end{array}$ & $\begin{array}{l}0.623 * * \\
(0.310)\end{array}$ & $\begin{array}{c}0.853 * * * \\
(0.111)\end{array}$ \\
\hline$R^{2}$ & 0.02 & 0.02 & 0.27 & 0.57 & 0.59 & 0.54 & 0.72 \\
\hline$N$ & 180,232 & 180,232 & 180,232 & 180,232 & 180,232 & 180,232 & 180,232 \\
\hline \multicolumn{8}{|l|}{ Fixed effects } \\
\hline Commuting zone & & & & $\mathrm{X}$ & $\mathrm{X}$ & & \\
\hline Three-digit ZIP code & & & & & & $\mathrm{X}$ & \\
\hline ZIP code & & & & & & & $\mathrm{X}$ \\
\hline
\end{tabular}

This table summarizes results from regressions of the percent of applications out of the commuting zone on the ZIP code-level home price decline. Where indicated, regressions include monthly measures of local labor market conditions and fixed effects for month, metropolitan statistical area (MSA), commuting zone, three-digit ZIP code, and five-digit ZIP code. Variables are defined as in Table 1. Regressions are weighted by the number of applications submitted from the ZIP code that month. Standard errors, adjusted for clustering at the ZIP code level, are reported in parentheses. $* *$ and $* * *$ indicate statistical significance at the $5 \%$ and $1 \%$ levels, respectively. 
Table 3

Number of applications

\begin{tabular}{lccccc}
\hline & \multicolumn{2}{c}{ In commuting zone } & & \multicolumn{2}{c}{ Out of commuting zone } \\
\cline { 2 - 3 } \cline { 5 - 6 } Dependent variable: & $\begin{array}{c}\text { Any } \\
\text { applications? }\end{array}$ & $\begin{array}{c}\text { Log applications } \\
\text { per worker }\end{array}$ & & $\begin{array}{c}\text { Any } \\
\text { applications? }\end{array}$ & $\begin{array}{c}\text { Log applications } \\
\text { per worker }\end{array}$ \\
\cline { 2 - 3 } Home value decline & $(1)$ & $(2)$ & & $(3)$ & $(4)$ \\
\cline { 2 - 3 } & $0.060^{* * *}$ & $0.002^{* * *}$ & & $-0.108^{* * *}$ & $-0.004^{* * *}$ \\
& $(0.021)$ & $(0.001)$ & & $(0.029)$ & $(0.001)$ \\
$R^{2}$ & & & & \\
$N$ & 0.39 & 0.65 & & 0.37 & 0.67 \\
& 180,232 & 158,452 & 180,232 & 134,746 \\
Local labor market conditions & $\mathrm{X}$ & & & \\
Fixed effects & & $\mathrm{X}$ & $\mathrm{X}$ & $\mathrm{X}$ \\
$\quad$ Month & $\mathrm{X}$ & $\mathrm{X}$ & & $\mathrm{X}$ & $\mathrm{X}$ \\
ZIP code & $\mathrm{X}$ & $\mathrm{X}$ & $\mathrm{X}$ & $\mathrm{X}$ \\
\hline
\end{tabular}

This table summarizes results from regressions of measures of the volume of applications on the ZIP code-level home value decline. Regressions include monthly measures of local labor market conditions and fixed effects for month and ZIP code. Variables are defined as in Table 1. Standard errors, adjusted for clustering at the ZIP code level, are reported in parentheses. ${ }^{* * *}$ indicates statistical significance at the $1 \%$ level. 
Table 4

Breadth of job search

\begin{tabular}{|c|c|c|c|c|c|}
\hline \multicolumn{5}{|c|}{ Dependent variable: Concentration of applications } & \multirow{3}{*}{$\begin{array}{c}\begin{array}{c}\text { Out of } \\
\text { commuting zone }\end{array} \\
(5)\end{array}$} \\
\hline & \multicolumn{4}{|c|}{ In commuting zone } & \\
\hline \multirow[b]{2}{*}{ Home value decline } & (1) & $(2)$ & (3) & (4) & \\
\hline & $\begin{array}{c}1.03 \\
(1.36)\end{array}$ & $\begin{array}{c}1.35 \\
(1.19)\end{array}$ & $\begin{array}{c}-4.77 * * * \\
(1.36)\end{array}$ & $\begin{array}{l}-2.88^{*} \\
(1.54)\end{array}$ & $\begin{array}{c}0.71 \\
(1.83)\end{array}$ \\
\hline$R^{2}$ & 0.42 & 0.51 & 0.52 & 0.68 & 0.59 \\
\hline$N$ & 158,598 & 158,598 & 158,598 & 158,598 & 134,872 \\
\hline $\begin{array}{l}\text { Local labor market conditions } \\
\text { Fixed effects }\end{array}$ & $\mathrm{X}$ & $\mathrm{X}$ & $\mathrm{X}$ & $\mathrm{X}$ & $\mathrm{X}$ \\
\hline Month & $\mathrm{X}$ & $\mathrm{X}$ & $\mathrm{X}$ & $\mathrm{X}$ & $\mathrm{X}$ \\
\hline MSA & $\mathrm{X}$ & & & & \\
\hline Commuting zone & & $\mathrm{X}$ & & & \\
\hline Three-digit ZIP code & & & $\mathrm{X}$ & & \\
\hline ZIP code & & & & $\mathrm{X}$ & $\mathrm{X}$ \\
\hline \multicolumn{6}{|c|}{$\begin{array}{l}\text { This table summarizes results from regressions of the concentration of applications on the ZIP code- } \\
\text { level home value decline. All regressions include monthly measures of local labor market conditions } \\
\text { and month fixed effects. Where indicated, regressions also include fixed effects for metropolitan } \\
\text { statistical area (MSA), commuting zone, three-digit ZIP code, and five-digit ZIP code. Variables are } \\
\text { defined as in Table } 1 \text {. Regressions are weighted by the number of applications submitted to jobs in } \\
\text { (columns 1-4) or out (column 5) of the commuting zone from the ZIP code that month. Standard errors, } \\
\text { adjusted for clustering at the ZIP code level, are reported in parentheses. * and *** indicate statistical } \\
\text { significance at the } 10 \% \text { and } 1 \% \text { level, respectively. }\end{array}$} \\
\hline
\end{tabular}


Table 5

Types of jobs

\begin{tabular}{|c|c|c|c|c|}
\hline Dependent variable: & Management & Executive & Entry level & $\begin{array}{c}\text { Requires }<1 \\
\text { year of } \\
\text { experience }\end{array}$ \\
\hline \multicolumn{5}{|c|}{ Panel A. In commuting zone } \\
\hline & $(1)$ & $(2)$ & $(3)$ & $(4)$ \\
\hline Home value decline & $\begin{array}{c}-0.024 * * \\
(0.010)\end{array}$ & $\begin{array}{c}-0.006^{* * *} \\
(0.001)\end{array}$ & $\begin{array}{c}0.007 \\
(0.009)\end{array}$ & $\begin{array}{l}0.470 * * * \\
(0.107)\end{array}$ \\
\hline$R^{2}$ & 0.32 & 0.12 & 0.16 & 0.61 \\
\hline$N$ & 158,598 & 158,598 & 158,598 & 40,984 \\
\hline \multicolumn{5}{|c|}{ Panel B. Out of commuting zone } \\
\hline & $(5)$ & $(6)$ & $(7)$ & $(8)$ \\
\hline Home value decline & $\begin{array}{l}0.012 \\
(0.014)\end{array}$ & $\begin{array}{c}0.000 \\
(0.003)\end{array}$ & $\begin{array}{c}-0.035 * * * \\
(0.013)\end{array}$ & $\begin{array}{l}-0.107 \\
(0.140)\end{array}$ \\
\hline$R^{2}$ & 0.19 & 0.12 & 0.15 & 0.47 \\
\hline$N$ & 134,872 & 134,872 & 134,872 & 29,628 \\
\hline $\begin{array}{l}\text { Local labor market conditions } \\
\text { Fixed effects }\end{array}$ & $\mathrm{X}$ & $\mathrm{X}$ & $X$ & $X$ \\
\hline Month & $\mathrm{X}$ & $\mathrm{X}$ & $X$ & $X$ \\
\hline ZIP code & $\mathrm{X}$ & $\mathrm{X}$ & $\mathrm{X}$ & $\mathrm{X}$ \\
\hline
\end{tabular}

This table summarizes results from regressions of measures of job type on the ZIP codelevel home value decline All regressions include monthly measures of local labor market conditions and fixed effects for month and ZIP code. Regressions are weighted by the number of applications submitted to jobs in (columns 1-3) or out (columns 5-7) of the commuting zone from the ZIP code that month or the number of number of applications submitted to jobs in (column 4) or out (column 8) of the commuting zone for which experience information is available. Variables are as defined in Table 1. Standard errors, adjusted for clustering at the ZIP code level, are reported in parentheses. ** and *** indicate statistical significance at the $5 \%$ and $1 \%$ level, respectively. 
Table 6

Falsification test: ZIP codes with predominantly renters

\begin{tabular}{|c|c|c|}
\hline Dependent variable: & $\begin{array}{l}\text { Percent of } \\
\text { applications out of } \\
\text { the commuting zone }\end{array}$ & $\begin{array}{l}\text { Concentration of } \\
\text { applications in the } \\
\text { commuting zone }\end{array}$ \\
\hline & $(1)$ & $(2)$ \\
\hline Home value decline & $\begin{array}{l}-0.027 \\
(0.070)\end{array}$ & $\begin{array}{l}-1.78 \\
(6.27)\end{array}$ \\
\hline$R^{2}$ & 0.87 & 0.55 \\
\hline$N$ & 4,166 & 3,997 \\
\hline $\begin{array}{l}\text { Local labor market conditions } \\
\text { Fixed effects }\end{array}$ & $\mathrm{X}$ & $\mathrm{X}$ \\
\hline Month & $\mathrm{X}$ & $\mathrm{X}$ \\
\hline ZIP code & $X$ & $X$ \\
\hline
\end{tabular}

This table summarizes results from regressions of the percent of applications out of the commuting zone or the concentration of applications in the commuting zone on the ZIP code-level home value decline, after restricting the sample to ZIP codes with homeownership rates below 25\%. Regressions include the monthly measures of local labor market conditions and fixed effects for month and ZIP code. The regression in column 1 is weighted by the total number of applications from the ZIP code that month, whereas the regression in column 2 is weighted by the number of applications submitted to jobs in the commuting zone. Variables are defined as in Table 1. Standard errors, adjusted for clustering at the ZIP code level, are reported in parentheses. 
Table 7

Importance of home equity

\begin{tabular}{|c|c|c|}
\hline \multirow[t]{2}{*}{ Dependent variable: } & $\begin{array}{l}\text { Percent of } \\
\text { applications out of } \\
\text { the commuting zone }\end{array}$ & $\begin{array}{l}\text { Concentration of } \\
\text { applications in the } \\
\text { commuting zone }\end{array}$ \\
\hline & $(1)$ & $(2)$ \\
\hline $\begin{array}{l}\text { Percent with low positive home equity } \\
{[0 \leq \mathrm{HE}<20 \%]}\end{array}$ & $\begin{array}{c}-0.071 * * * \\
(0.022)\end{array}$ & $\begin{array}{l}-13.23 * * * \\
(2.18)\end{array}$ \\
\hline $\begin{array}{l}\text { Percent with negative home equity } \\
{[\mathrm{HE}<0]}\end{array}$ & $\begin{array}{l}-0.126 * * * \\
(0.017)\end{array}$ & $\begin{array}{r}-3.17 * * \\
(1.59)\end{array}$ \\
\hline $\begin{array}{l}R^{2} \\
N\end{array}$ & $\begin{array}{c}0.72 \\
180,161\end{array}$ & $\begin{array}{c}0.68 \\
158,540\end{array}$ \\
\hline Local labor market conditions & $X$ & $X$ \\
\hline $\begin{array}{l}\text { F1xed effects } \\
\text { Month } \\
\text { ZIP code }\end{array}$ & $\begin{array}{l}X \\
X\end{array}$ & $\begin{array}{l}X \\
X\end{array}$ \\
\hline $\begin{array}{l}\text { This table summarizes results from reg } \\
\text { the commuting zone or the concentrati } \\
\text { the percent of mortgagors in the ZIP } \\
\text { (HE). Regressions include the monthly } \\
\text { fixed effects for month and ZIP code. T } \\
\text { total number of applications from the Z } \\
\text { column } 2 \text { is weighted by the numbe } \\
\text { commuting zone. Variables are definec }\end{array}$ & $\begin{array}{l}\text { essions of the percen } \\
n \text { of applications in } t \\
\text { ode with different an } \\
\text { leasures of local labor } \\
\text { e regression in colum } \\
\text { code that month, wl } \\
\text { of applications sub } \\
\text { as in Table 1. Stand } \\
\text { ported in parentheses } \\
\text { levels, respectively. }\end{array}$ & $\begin{array}{l}f \text { applications out of } \\
\text { commuting zone on } \\
\text { unts of home equity } \\
\text { larket conditions and } \\
1 \text { is weighted by the } \\
\text { eas the regression in } \\
\text { itted to jobs in the } \\
1 \text { errors, adjusted for } \\
* * \text { and } * * * \text { indicate }\end{array}$ \\
\hline
\end{tabular}


Table 8

Importance of recourse laws

\begin{tabular}{lcc}
\hline Dependent variable: & $\begin{array}{c}\text { Percent of } \\
\text { applications out of } \\
\text { the commuting zone }\end{array}$ & $\begin{array}{c}\text { Concentration of } \\
\text { applications in the } \\
\text { commuting zone }\end{array}$ \\
\cline { 2 - 3 } Home value decline & $\begin{array}{c}(1) \\
(0.008)\end{array}$ & $6.84^{*}$ \\
& & $(3.74)$ \\
Home value decline $\times$ Recourse & $-0.169^{* * *}$ & $-10.40^{* * * *}$ \\
& $(0.047)$ & $(3.99)$ \\
$R^{2}$ & & 0.68 \\
$N$ & 0.72 & 158,598 \\
Local labor market conditions & 180,232 & $\mathrm{X}$ \\
Fixed effects & $\mathrm{X}$ & $\mathrm{X}$ \\
Month $\times$ Recourse & $\mathrm{X}$ & $\mathrm{X}$ \\
ZIP code & $\mathrm{X}$ & \\
\hline
\end{tabular}

This table summarizes results from regressions of the percent of applications out of the commuting zone or the concentration of applications in the commuting zone on the ZIP code-level home value decline and its interaction with an indicator for whether mortgage lenders in the state typically have recourse against borrowers' other assets. All regressions include monthly measures of local labor market conditions and fixed effects for month and ZIP code. The main effect of recourse is absorbed by the ZIP code fixed effects. The regression in column 1 is weighted by the total number of applications from the ZIP code that month, whereas the regression in column 2 is weighted by the number of applications submitted to jobs in the commuting zone. Variables are defined as in Table 1. Standard errors, adjusted for clustering at the ZIP code level, are reported in parentheses. ${ }^{*}$ and $* * *$ indicate statistical significance at the $10 \%$ and $1 \%$ level, respectively. 
Table 9

Characteristics of ZIP codes near state borders

\begin{tabular}{|c|c|c|c|c|c|}
\hline \multirow[b]{3}{*}{ Population density (people per square mile) } & \multicolumn{2}{|c|}{$\begin{array}{c}\text { Nonrecourse } \\
(N=997)\end{array}$} & \multicolumn{2}{|c|}{$\begin{array}{c}\text { Recourse } \\
(N=1,070)\end{array}$} & \multirow{2}{*}{$\begin{array}{l}p \text { - value of } \\
\text { difference }\end{array}$} \\
\hline & Mean & $S D$ & Mean & $S D$ & \\
\hline & 199 & 725 & 605 & 2,133 & 0.16 \\
\hline Owner occupied (\%) & 76.8 & 11.5 & 76.6 & 13.1 & 0.88 \\
\hline Mobility (different county from 5 years ago, \%) & 0.2 & 0.1 & 0.2 & 0.1 & 0.58 \\
\hline Mean commute time (minutes) & 22.8 & 6.7 & 24.0 & 6.9 & 0.18 \\
\hline Distance to commuting zone border (miles) & 13.3 & 10.0 & 17.5 & 13.8 & 0.12 \\
\hline \multicolumn{6}{|l|}{ Home equity $(\%)$} \\
\hline Low positive $[0 \leq \mathrm{HE}<20 \%]$ & 22.9 & 8.4 & 23.5 & 7.7 & 0.83 \\
\hline Negative $[\mathrm{HE}<0]$ & 6.9 & 7.7 & 16.5 & 20.1 & 0.31 \\
\hline \multicolumn{6}{|l|}{ Demographics } \\
\hline Male (\%) & 50.3 & 2.1 & 50.4 & 2.9 & 0.81 \\
\hline Married (\%) & 0.3 & 0.0 & 0.3 & 0.0 & 0.65 \\
\hline Mean household size & 2.5 & 0.3 & 2.6 & 0.3 & 0.12 \\
\hline \multicolumn{6}{|l|}{ Age $(\%)$} \\
\hline Less than 5 years old & 5.9 & 1.7 & 6.4 & 2.7 & 0.01 \\
\hline 5 to 9 years old & 7.0 & 1.8 & 7.2 & 1.8 & 0.40 \\
\hline 10 to 14 years old & 7.8 & 1.9 & 7.9 & 2.0 & 0.81 \\
\hline 15 to 19 years old & 7.6 & 2.8 & 7.5 & 2.5 & 0.83 \\
\hline 20 to 24 years old & 4.7 & 2.8 & 4.9 & 3.1 & 0.30 \\
\hline 25 to 34 years old & 10.7 & 2.7 & 11.3 & 3.5 & 0.20 \\
\hline 35 to 44 years old & 15.5 & 2.5 & 15.5 & 2.6 & 0.99 \\
\hline 45 to 54 years old & 14.3 & 2.6 & 14.2 & 3.2 & 0.82 \\
\hline 55 to 59 years old & 5.5 & 1.6 & 5.6 & 1.8 & 0.81 \\
\hline 60 to 64 years old & 4.9 & 1.7 & 4.8 & 1.8 & 0.73 \\
\hline Over 65 years old & 16.1 & 5.9 & 14.7 & 5.6 & 0.08 \\
\hline \multicolumn{6}{|l|}{ Race $(\%)$} \\
\hline White & 93.2 & 15.2 & 90.8 & 15.7 & 0.43 \\
\hline Black & 0.6 & 2.0 & 1.5 & 5.2 & 0.09 \\
\hline Asian & 0.5 & 0.9 & 1.2 & 2.9 & 0.15 \\
\hline Hispanic & 3.2 & 7.8 & 4.6 & 8.6 & 0.40 \\
\hline \multicolumn{6}{|l|}{ Education (\%) } \\
\hline High school & 38.1 & 8.8 & 35.9 & 10.4 & 0.37 \\
\hline Some college & 7.1 & 3.2 & 6.4 & 3.0 & 0.12 \\
\hline College & 11.1 & 6.5 & 12.4 & 7.5 & 0.24 \\
\hline Graduate school & 4.3 & 3.7 & 5.5 & 5.3 & 0.14 \\
\hline
\end{tabular}


Table 9 (continued)

Household income $(\%)$

$\begin{array}{lccccc}\text { Less than } \$ 10,000 & 10.1 & 7.0 & 9.4 & 6.8 & 0.71 \\ \$ 10,000 \text { to } \$ 15,000 & 7.7 & 4.0 & 7.2 & 5.4 & 0.59 \\ \$ 15,000 \text { to } \$ 25,000 & 15.6 & 5.5 & 14.7 & 6.9 & 0.44 \\ \$ 25,000 \text { to } \$ 35,000 & 15.2 & 4.7 & 14.5 & 5.8 & 0.37 \\ \$ 35,000 \text { to } \$ 50,000 & 19.1 & 5.6 & 18.6 & 6.7 & 0.49 \\ \$ 50,000 \text { to } \$ 75,000 & 19.5 & 6.6 & 19.5 & 7.3 & 0.98 \\ \$ 75,000 \text { to } \$ 100,000 & 7.4 & 4.5 & 8.0 & 5.3 & 0.63 \\ \$ 100,000 \text { to } \$ 150,000 & 3.8 & 3.1 & 5.1 & 5.2 & 0.24 \\ \$ 150,000 \text { to } \$ 200,000 & 0.8 & 1.0 & 1.3 & 2.2 & 0.11 \\ \text { Over } \$ 200,000 & 0.9 & 1.1 & 1.6 & 3.9 & 0.13\end{array}$

This table reports summary statistics for ZIP codes within 50 miles of state borders where the recourse law changes. Means, standard deviations, and $p$-values of the difference in means, adjusted for clustering at the state level, are reported. Home equity measures are ZIP code averages for May 2008 to December 2009, estimated from CoreLogic's Loan-Level Market Analytics database. Distance to commuting zone border is the geodesic distance. All other ZIP code characteristics are from the 2000 U.S. Census. 
Table 10

Applications out of the commuting zone and recourse laws, regression discontinuity analysis

\begin{tabular}{|c|c|c|c|c|c|c|}
\hline \multirow[b]{3}{*}{ Recourse } & \multicolumn{2}{|c|}{ All ZIP codes } & \multirow{2}{*}{$\begin{array}{l}\text { High income } \\
\text { ZIP codes } \\
(3)\end{array}$} & \multirow{2}{*}{$\begin{array}{c}\text { Low income } \\
\text { ZIP codes } \\
(4)\end{array}$} & \multicolumn{2}{|c|}{ High income ZIP codes } \\
\hline & (1) & (2) & & & (5) & (6) \\
\hline & $\begin{array}{c}-36.7^{* * * *} \\
(9.1)\end{array}$ & $\begin{array}{c}-21.1 * * * \\
(6.7)\end{array}$ & $\begin{array}{c}-22.5^{* * *} \\
(5.9)\end{array}$ & $\begin{array}{c}1.6 \\
(7.4)\end{array}$ & $\begin{array}{c}-23.2^{* *} \\
(7.8)\end{array}$ & $\begin{array}{c}-24.4 * * * \\
(6.7)\end{array}$ \\
\hline $\begin{array}{l}\text { Recourse } \\
\times \text { Above median price drop }\end{array}$ & & & & & & $\begin{array}{c}-6.1^{* *} \\
(2.5)\end{array}$ \\
\hline$R^{2}$ & 0.60 & 0.60 & 0.60 & 0.70 & 0.54 & 0.53 \\
\hline$N$ & 10,874 & 10,874 & 8,774 & 2,097 & 5,838 & 6,404 \\
\hline
\end{tabular}

Fixed effects

\begin{tabular}{|c|c|c|c|c|c|}
\hline Month & $\mathrm{X}$ & $\mathrm{X}$ & $\mathrm{X}$ & $\mathrm{X}$ & $\mathrm{X}$ \\
\hline Border strip $\times$ commuting zone & $X$ & $\mathrm{X}$ & $\mathrm{X}$ & $\mathrm{X}$ & $\mathrm{X}$ \\
\hline Distance to border & & $\mathrm{X}$ & $\mathrm{X}$ & $\mathrm{X}$ & $\mathrm{X}$ \\
\hline Distance to border squared & & $\mathrm{X}$ & $\mathrm{X}$ & $\mathrm{X}$ & $\mathrm{X}$ \\
\hline Distance to border cubed & & $\mathrm{X}$ & $\mathrm{X}$ & $\mathrm{X}$ & $\mathrm{X}$ \\
\hline IP code age and race controls & & & & & $\mathrm{X}$ \\
\hline
\end{tabular}

This table summarizes results from regressions of the percent of applications out of the commuting zone on an indicator for whether mortgage lenders in the state typically have recourse against borrowers' other assets, after restricting the sample to ZIP codes within 50 miles of state borders where recourse law changes. All regressions include month and location (10mile border strip $\times$ commuting zone) fixed effects. Where indicated, regressions include controls for distance to the state border, and the age and race variables listed in Table 9. High (low) wealth ZIP codes are ones with above (below) median adjusted gross income in 2006. The specification in column 6 includes an uninteracted indicator for ZIP codes that experienced an above median price decline. Variables are defined as in Table 1. Regressions are weighted by the number of applications submitted from the ZIP code that month. Standard errors, adjusted for clustering at the state level, are reported in parentheses. ${ }^{* *}$ and $* * *$ indicate statistical significance at the $5 \%$ and $1 \%$ level, respectively. 
Table 11

Breadth of job search and recourse laws, regression discontinuity analysis

\begin{tabular}{|c|c|c|c|c|c|c|c|}
\hline & \multicolumn{6}{|c|}{ In commuting zone } & \multirow{2}{*}{$\begin{array}{l}\text { Out of zone } \\
\text { des }\end{array}$} \\
\hline & \multicolumn{2}{|c|}{ All ZIP codes } & \multirow{2}{*}{$\begin{array}{l}\text { High income } \\
\text { ZIP codes } \\
(3)\end{array}$} & \multirow{2}{*}{$\begin{array}{l}\text { Low income } \\
\text { ZIP codes } \\
(4)\end{array}$} & \multicolumn{2}{|c|}{ High income ZIP codes } & \\
\hline & $(1)$ & $(2)$ & & & $(5)$ & $(6)$ & $(7)$ \\
\hline Recourse & $\begin{array}{c}-1879 * * * \\
(478)\end{array}$ & $\begin{array}{c}-1006^{* *} \\
(361)\end{array}$ & $\begin{array}{c}-1232 * * * \\
(191)\end{array}$ & $\begin{array}{c}739 \\
(808)\end{array}$ & $\begin{array}{c}-1080^{* * *} \\
(196)\end{array}$ & $\begin{array}{c}-1099 * * * \\
(168)\end{array}$ & $\begin{array}{c}832 \\
(683)\end{array}$ \\
\hline $\begin{array}{l}\text { Recourse } \\
\times \text { Above median price drop }\end{array}$ & & & & & & $\begin{array}{c}-328 * * * \\
(67)\end{array}$ & \\
\hline$R^{2}$ & 0.65 & 0.66 & 0.65 & 0.64 & 0.67 & 0.65 & 0.32 \\
\hline$N$ & 7,898 & 7,898 & 6,808 & 1,087 & 5,141 & 5,484 & 6,195 \\
\hline \multicolumn{8}{|l|}{ Fixed effects } \\
\hline Month & $\mathrm{X}$ & $\mathrm{X}$ & $X$ & $\mathrm{X}$ & $X$ & $\mathrm{X}$ & $\mathrm{X}$ \\
\hline Border strip $\times$ commuting zone & $\mathrm{X}$ & $\mathrm{X}$ & $\mathrm{X}$ & $\mathrm{X}$ & $X$ & $\mathrm{X}$ & $\mathrm{X}$ \\
\hline Distance to border & & $\mathrm{X}$ & $\mathrm{X}$ & $\mathrm{X}$ & $X$ & $\mathrm{X}$ & $\mathrm{X}$ \\
\hline Distance to border squared & & $\mathrm{X}$ & $\mathrm{X}$ & $\mathrm{X}$ & $X$ & $\mathrm{X}$ & $\mathrm{X}$ \\
\hline Distance to border cubed & & $X$ & $X$ & $X$ & $X$ & $\mathrm{X}$ & $X$ \\
\hline ZIP code age and race controls & & & & & $X$ & & \\
\hline
\end{tabular}


Table 12

Number of applications and recourse laws, regression discontinuity analysis

\begin{tabular}{lcccc}
\hline & & & & \multicolumn{2}{c}{$\begin{array}{c}\text { Requires }<1 \\
\text { year of } \\
\end{array}$} \\
& Management & Executive & Entry level & \begin{tabular}{c} 
experience \\
\cline { 2 - 5 }
\end{tabular} \\
\cline { 2 - 5 } Recourse & Panel A. In commuting zone & & $(4)$ \\
\cline { 2 - 5 } & $(1)$ & $(2)$ & $1.51^{*}$ & $6.07 * * *$ \\
$R^{2}$ & $-1.59 * *$ & -0.15 & $(0.76)$ & $(0.90)$ \\
$N$ & $(0.58)$ & $(0.18)$ & & 0.16 \\
& & & & \\
& 0.36 & 0.11 & 0.30 & 1,487
\end{tabular}

Panel B. Out of commuting zone

Recourse

\begin{tabular}{cccc}
$(5)$ & $(6)$ & $(7)$ & $(8)$ \\
\hline $2.92 * * *$ & 0.31 & -0.29 & 1.68 \\
$(0.93)$ & $(0.27)$ & $(0.88)$ & $(2.70)$
\end{tabular}

$R^{2}$

0.07

0.08

0.06

0.17

$N$

6,195

6,195

6,195

1,247

Fixed effects

Month

Border strip $\times$ commuting zone

Distance to border

Distance to border squared

Distance to border cubed

\begin{tabular}{llll}
$X$ & $X$ & $X$ & $X$ \\
$X$ & $X$ & $X$ & $X$ \\
$X$ & $X$ & $X$ & $X$ \\
$X$ & $X$ & $X$ & $X$ \\
$X$ & $X$ & $X$ & $X$ \\
\hline
\end{tabular}

This table summarizes results from regressions of measures of job type on an indicator for whether mortgage lenders in the state typically have recourse against borrowers' other assets, after restricting the sample to ZIP codes within 50 miles of state borders where recourse law changes. The specification is the same as in column 3 of Table 10. Regressions are weighted by the number of applications submitted to jobs in (columns 1-3) or out (columns 5-7) of the commuting zone from the ZIP code that month, respectively, or the number of number of applications submitted to jobs in (column 4) or out (column 8) of the commuting zone for which experience information is available. Variables are as defined in Table 1. Standard errors, adjusted for clustering at the state level, are reported in parentheses. $* * *$, and $* * *$ indicate statistical significance at the $10 \%, 5 \%$, and $1 \%$ level, respectively. 


\section{Appendix Figure A1 \\ Volume of applications in and out of the commuting zone}

Panel A. In commuting zone

Any applications?

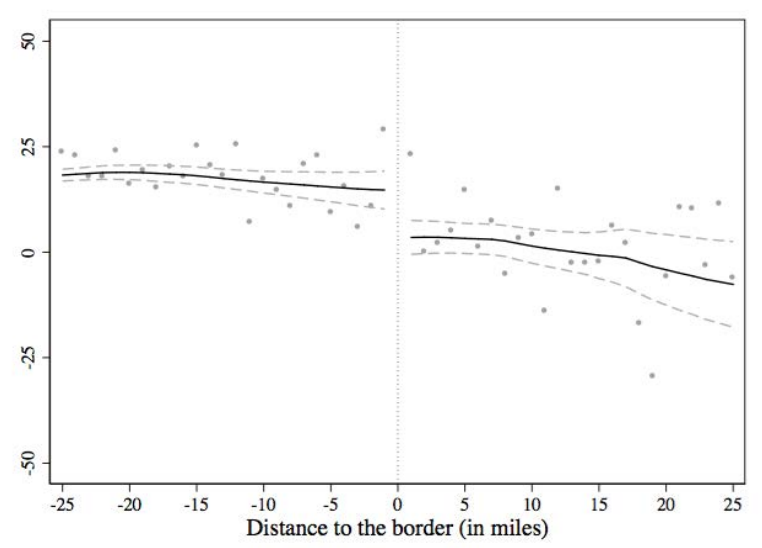

Log applications per worker

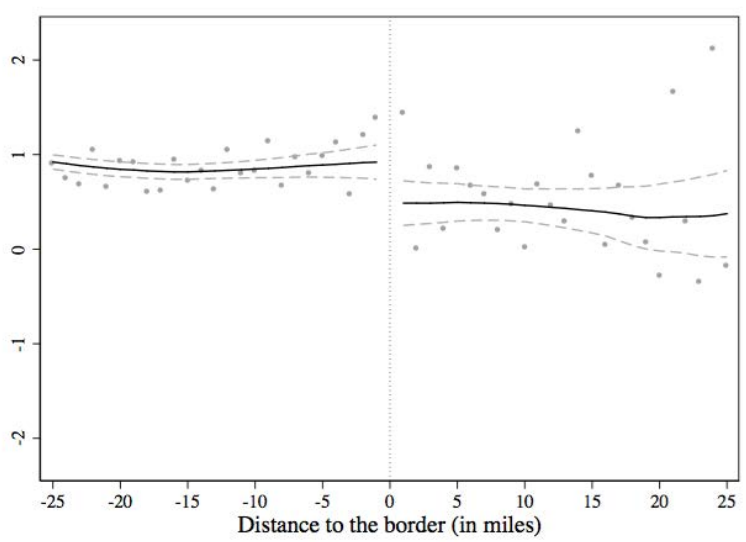

Panel B. Out of commuting zone

Any applications?

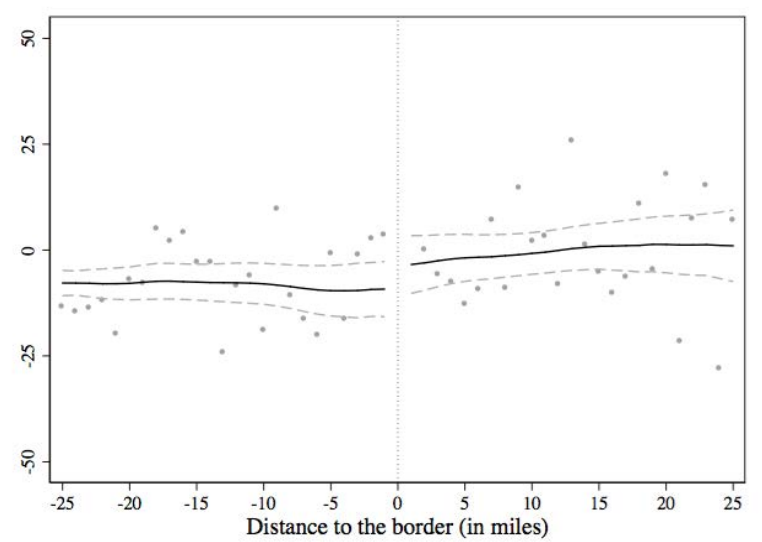

Log applications per worker

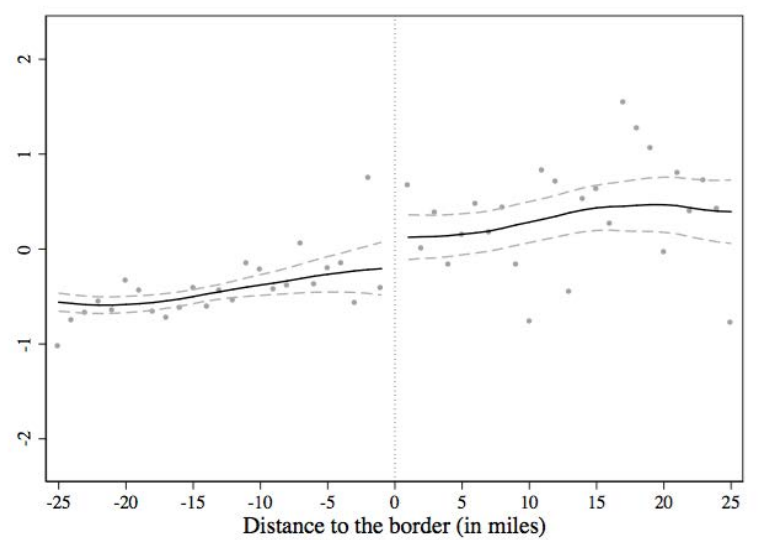

These figures plot indicators for any applications or the number of applications to jobs in (Panel A) or out (Panel B) of the commuting zone for the months between May 2008 and December 2009 for U.S. ZIP codes that are near a state border where recourse law changes and had above median adjusted gross income in 2006. Variables are defined as in Table 1, and the methodology used is the same as in Figure 3. The distances are labeled as negative for states with recourse mortgages. 


\section{Appendix Figure A2}

\section{Types of jobs applied for in the commuting zone}

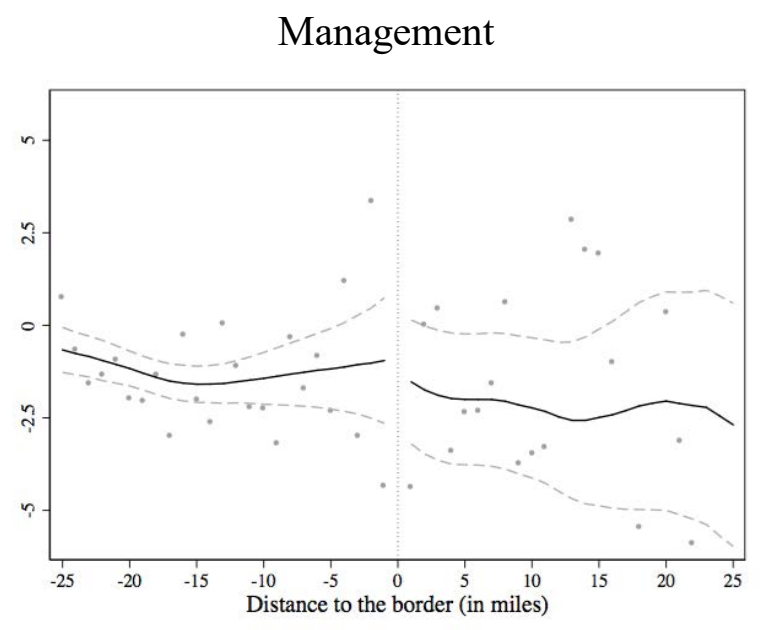

Entry level

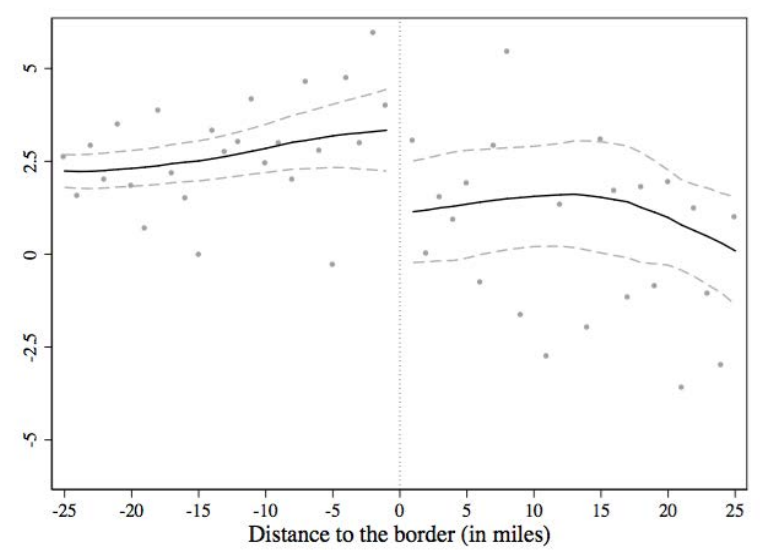

Executive

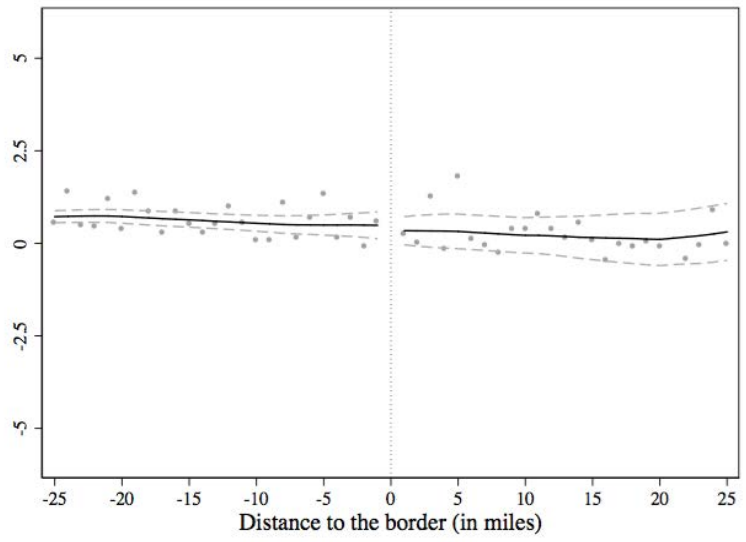

Requires $<1$ year of experience

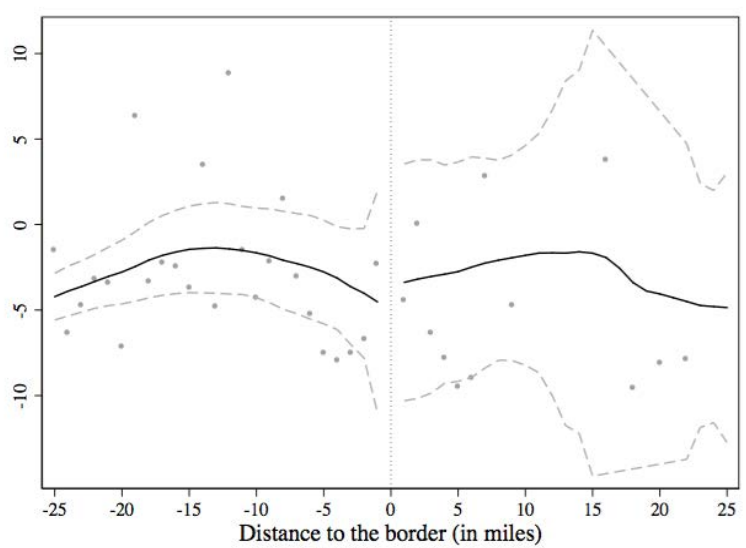

These figures plot the percent of applications in the commuting zone submitted to jobs of various types for the months between May 2008 and December 2009 for U.S. ZIP codes that are near a state border where recourse law changes and had above median adjusted gross income in 2006. Variables are defined as in Table 1, and the methodology used is the same as in Figure 3. The distances are labeled as negative for states with recourse mortgages. 


\section{Appendix Figure A3}

Types of jobs applied for out of the commuting zone
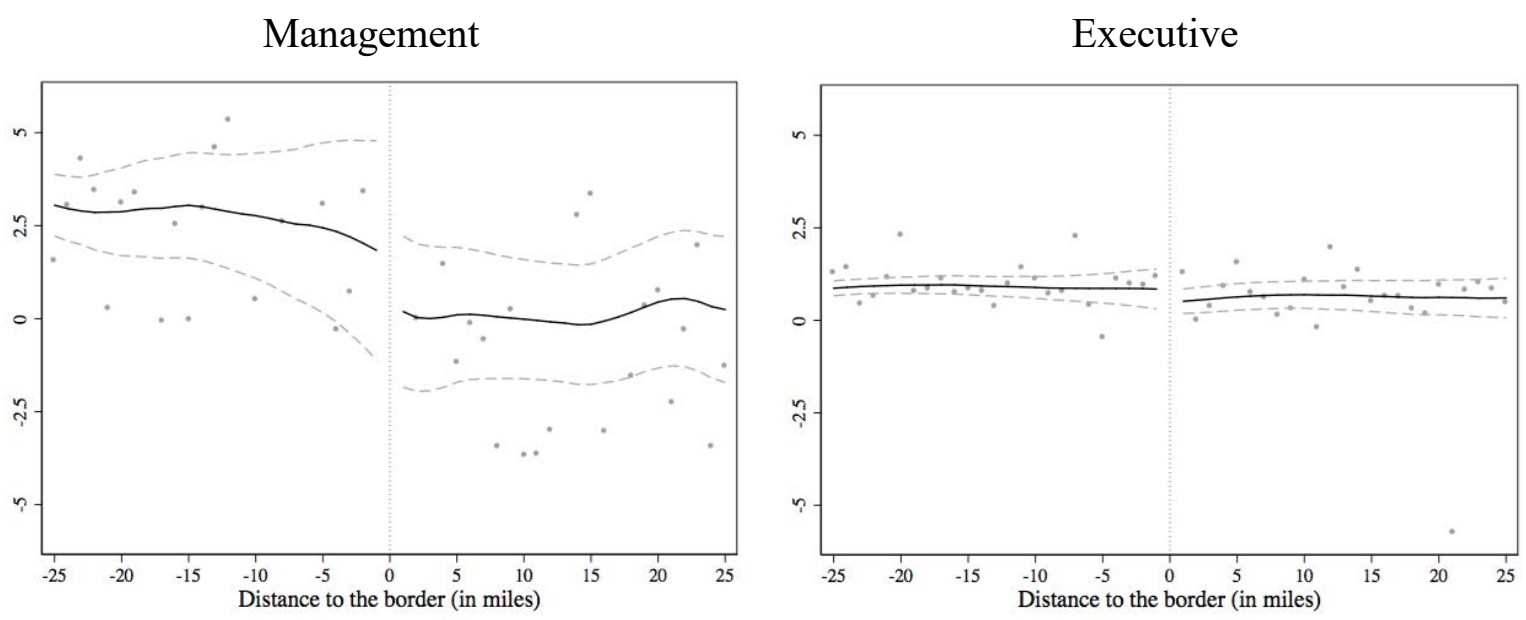

Entry level

Requires $<1$ year of experience
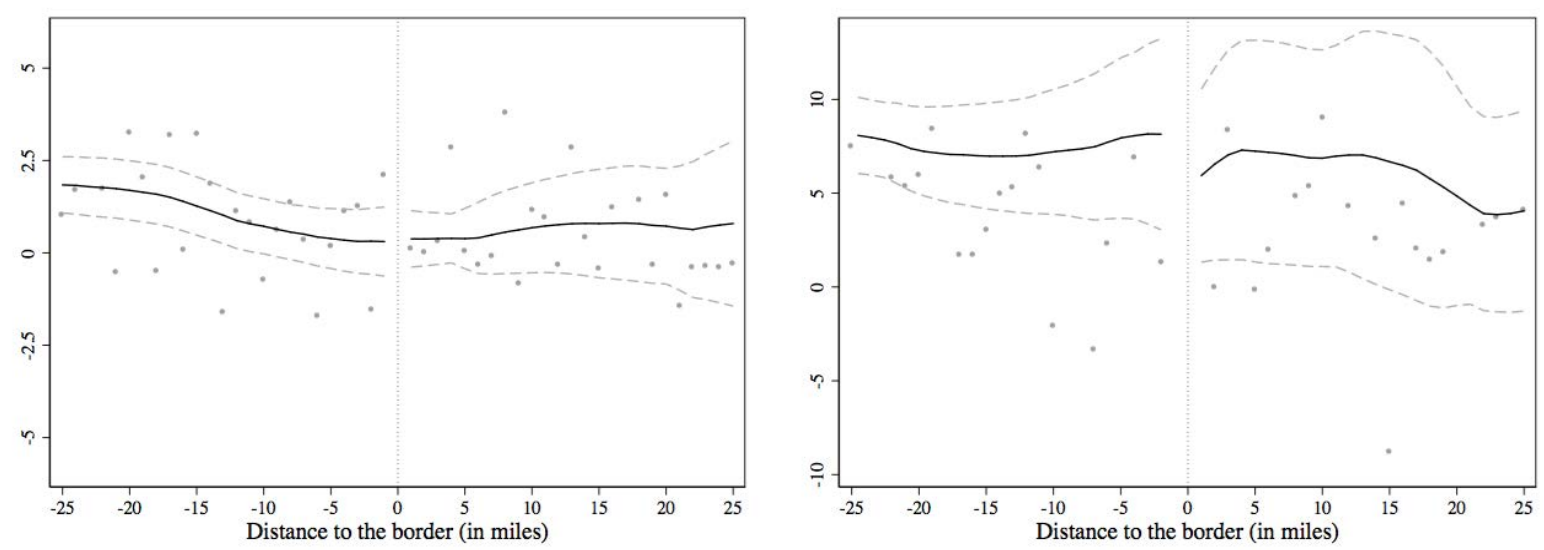

These figures plot the percent of applications out of the commuting zone submitted to jobs of various types for the months between May 2008 and December 2009 for U.S. ZIP codes that are near a state border where recourse law changes and had above median adjusted gross income in 2006. Variables are defined as in Table 1, and the methodology used is the same as in Figure 3. The distances are labeled as negative for states with recourse mortgages. 


\section{Appendix Table A1}

Number of applications and recourse laws, regression discontinuity analysis

\begin{tabular}{|c|c|c|c|c|}
\hline \multirow{3}{*}{ Dependent variable: } & \multicolumn{2}{|c|}{ In commuting zone } & \multicolumn{2}{|c|}{ Out of commuting zone } \\
\hline & $\begin{array}{c}\text { Any } \\
\text { applications? }\end{array}$ & $\begin{array}{c}\text { Log } \\
\text { applications } \\
\text { per worker } \\
\end{array}$ & $\begin{array}{c}\text { Any } \\
\text { applications? }\end{array}$ & $\begin{array}{c}\text { Log } \\
\text { applications } \\
\text { per worker }\end{array}$ \\
\hline & $(1)$ & $(2)$ & $(3)$ & $(4)$ \\
\hline Recourse & $\begin{array}{l}8.66^{*} \\
(4.83)\end{array}$ & $\begin{array}{c}0.30 \\
(0.23)\end{array}$ & $\begin{array}{l}-5.77 \\
(6.29)\end{array}$ & $\begin{array}{l}-0.35 \\
(0.34)\end{array}$ \\
\hline$R^{2}$ & 0.51 & 0.51 & 0.21 & 0.45 \\
\hline$N$ & 8,743 & 6,795 & 8,743 & 6,177 \\
\hline Fixed effects & & & & \\
\hline Month & $X$ & $\mathrm{X}$ & $\mathrm{X}$ & $\mathrm{X}$ \\
\hline Border strip $\times$ commuting zone & $\mathrm{X}$ & $\mathrm{X}$ & $\mathrm{X}$ & $\mathrm{X}$ \\
\hline Distance to border & $\mathrm{X}$ & $\mathrm{X}$ & $\mathrm{X}$ & $\mathrm{X}$ \\
\hline Distance to border squared & $\mathrm{X}$ & $\mathrm{X}$ & $\mathrm{X}$ & $\mathrm{X}$ \\
\hline Distance to border cubed & $\mathrm{X}$ & $\mathrm{X}$ & $\mathrm{X}$ & $\mathrm{X}$ \\
\hline
\end{tabular}

This table summarizes results from regressions of measures of the volume of applications on an indicator for whether mortgage lenders in the state typically have recourse against borrowers' other assets, after restricting the sample to ZIP codes within 50 miles of state borders where recourse law changes. The specification is the same as in column 3 of Table 10. Variables are defined as in Table 1. Standard errors, adjusted for clustering at the state level, are reported in parentheses. 